\title{
Seasonal variation in photosynthesis performance of cassava at two different growth stages under irrigated and rain-fed conditions in a tropical savanna climate
}

\author{
K. VONGCHAROEN ${ }^{*}$, S. SANTANOO ${ }^{* *}$, P. BANTERNG ${ }^{* * *}$, S. JOGLOY ${ }^{* * *}$, N. VORASOOT ${ }^{* * *}$, \\ and P. THEERAKULPISUT ${ }^{*, * *,+}$ \\ Department of Biology, Faculty of Science, Khon Kaen University, Khon Kaen 40002, Thailand ${ }^{*}$ \\ Salt-tolerant Rice Research Group, Department of Biology, Faculty of Science, Khon Kaen University, Khon Kaen 40002, \\ Thailand** \\ Department of Plant Science and Agricultural Resources, Faculty of Agriculture, Khon Kaen University, Khon Kaen \\ 40002, Thailand ${ }^{* * *}$
}

\begin{abstract}
Seasonal variations in photosynthesis of cassava cv. Rayong 9 (RY9) under irrigated and rain-fed conditions were evaluated at the age of three and six months after planting (MAP). Photosynthetic light-response $\left(P_{\mathrm{N}} / I\right)$ curves revealed that cassava leaves attained the highest maximum net photosynthetic rates $\left(P_{\mathrm{Nmax}}\right)$ in the rainy season, followed by the hot one, while the lowest $P_{\mathrm{Nmax}}$ was found in the cool season. Photosynthetic potential of the 3-month-old plants was mostly higher than that of the 6-month-old plants, and the seasonal variation in photosynthetic capacity was also more apparent in the younger plants. $P_{\mathrm{N}} / I$ curves were used to predict daily net photosynthetic rate $\left(P_{\mathrm{N}}\right)$ for each season based on daily average solar radiation data. The predicted $P_{\mathrm{N}}$ were considerably lower than the $P_{\mathrm{Nmax}}$ values. This indicated that solar radiation is a limiting factor for photosynthesis, particularly in the rainy season. The data provided basic information for breeding cassava genotypes with enhanced photosynthesis during the period of unfavorable environment. Furthermore, the data are potentially useful in modeling photosynthesis and crop growth as affected by environmental factors.
\end{abstract}

Additional key words: canopy; leaf gas exchange; light-response curve; Manihot esculenta.

\section{Introduction}

Cassava (Manihot esculenta Crantz) is one of the most important food and energy crop which is cultivated in many countries in the tropical and subtropical zones of Africa, Asia, and Latin America (El-Sharkawy 2006, Okogbenin et al. 2013). In Africa, cassava is considered the second most important source of daily calorie consumption for rural poor, while in Asia and Latin America, it is also grown commercially as an important cash crop on large fields (Nassar and Ortiz 2010). In terms of total production of cassava roots in Asia, 78\% is exported in the forms of cassava chips and pellets (39\%) and cassava starch (39\%). For domestic consumption (22\%), 3\% goes to cassava chips and pellets, $14 \%$ to cassava starch, and $4 \%$ to ethanol, etc. (Newby 2016). Globally, Thailand was the second largest producer of cassava, after Nigeria, in 2013 and 2014 (FAO 2016). Average world cassava dry root yield was estimated at $4 \mathrm{tha}^{-1}$, while experimental yield of improved cultivars grown at near optimal climatic conditions in fertile soils exceeded $20 \mathrm{t} \mathrm{ha}^{-1}$ (El-Sharkawy and Cock 1990, El-Sharkawy et al. 1993). However, the main causes of low yields in developing countries, including Thailand, are poor soils, inadequate crop

Received 3 November 2017, accepted 9 March 2018, published as online-first 16 July 2018.

${ }^{+}$Corresponding author; e-mail: piythe@kku.ac.th

Abbreviations: $\mathrm{AQE}$ - apparent quantum yield; $C_{\mathrm{i}}$ - intercellular $\mathrm{CO}_{2}$ concentration; $E$ - transpiration rate; $g_{\mathrm{s}}$ - stomatal conductance; $I$ - photosynthetic photon flux density; $I_{\text {comp }}$ - light-compensation point; $I_{\text {sat }}$ - light-saturation point; $P_{\mathrm{N}}$ - net photosynthetic rate; $P$ gmax - light-saturated gross photosynthetic rate; $P_{\mathrm{Nmax}}-$ maximum net photosynthetic rate; $P_{\mathrm{N}} / I-$ photosynthetic light-response curves; $R^{2}$ - coefficient of determination; $R_{\mathrm{D}}$ - dark respiration rate; WUE - water-use efficiency.

Acknowledgements: This project was financially supported by the Thailand Research Organizations Network (TRON) administered by the National Science and Technology Development Agency (NSTDA). The authors also acknowledge the Thailand Research Fund (Project code: IRG5780003) and Faculty of Agriculture, Khon Kaen University for providing financial support for manuscript preparation activities. 
management, water shortage, pests, and diseases (Vongkasem et al. 2000). The yield gap has been exacerbated by increasing intensity of abiotic stresses caused by global warming. It was reported that productivity was closely associated with measured $P_{\mathrm{N}}$ from studies across a large group of accessions (Lenis et al. 2006, El-Sharkawy 2010). Yield improvement in cassava could be achieved by selecting genotypes with high photosynthetic potentials incorporated into the breeding program (El-Sharkawy 2009a, Mulualem and Bekeko 2015). Cassava breeding over the past 30-40 years has focused upon increasing harvest index which increases the proportion of total plant biomass partitioned to the harvested storage roots. However, the total plant biomass, which results from photosynthesis activity integrated over the growing season, places a limit on the absolute increase in the yield. Therefore, increasing the light interception efficiency of PAR as well as the efficiency of conversion of intercepted PAR to biomass, through photosynthesis, are becoming main opportunities for genetic improvement of the yield potential (de Souza et al. 2017).

In comparison to most $C_{3}$ food crops, cassava has been reported to be well adapted to tropical environments, requiring high temperature and high solar radiation for optimum leaf growth and photosynthetic potential (Keating and Evenson 1979, El-Sharkawy et al. 1992a). Strikingly high photosynthetic potential approaching that of $\mathrm{C}_{4}$ plants, i.e., $P_{\mathrm{N}}$ greater than $40 \mu \mathrm{mol}\left(\mathrm{CO}_{2}\right) \mathrm{m}^{-1} \mathrm{~s}^{-1}$, has been observed in cassava grown under favorable conditions (El-Sharkawy et al. 1992a, El-Sharkawy 2016), nevertheless, they can maintain relatively high photosynthetic capacity under stressful environments (de Tafur et al. 1997, El-Sharkawy and de Tafur 2007). Optimum temperature for growth, yield, and maximum photosynthesis was $25-35^{\circ} \mathrm{C}$ (El-Sharkawy et al. 1992a,b). Temperature below $17^{\circ} \mathrm{C}$ or above $37^{\circ} \mathrm{C}$ inhibited leaf growth of cassava, and temperature below $20^{\circ} \mathrm{C}$ decreased photosynthetic rate (Keating and Evenson 1979, ElSharkawy 2012). Cassava stomata were found to partially close in low air humidity with virtually no changes in leaf water potential, and also in response to soil water shortage, hence, protecting the leaf from severe dehydration and at the same time the leaf remained photosynthetically active (El-Sharkawy 2004, 2007). Stomata readily close in dry air and nearly complete stomatal closure occurs during soil water deficit (El-Sharkawy and Cock 1984, Calatayud et al. 2000, El-Sharkawy 2004, 2007). Cassava leaf $P_{\mathrm{N}}$ (measured during the driest period of the year) varied among cultivars from $25-31 \mu \mathrm{mol}\left(\mathrm{CO}_{2}\right) \mathrm{m}^{-2} \mathrm{~s}^{-1}$ in seasonally dry and $7-20 \mu \mathrm{mol}\left(\mathrm{CO}_{2}\right) \mathrm{m}^{-2} \mathrm{~s}^{-1}$ in the semiarid environment due to lower air humidity and greater soil water deficit in the latter one (de Tafur et al. 1997). Photosynthesis potential of cassava leaves also varied depending on plant traits including plant age, leaf age and position, leaf area index, leaf duration, leaf longevity, and the environments under which the leaves were developing (El-Sharkawy et al. 1992a, Lawlor 2001, El-Sharkawy
2012). Leaves which developed during the period of low temperatures $\left(<20^{\circ} \mathrm{C}\right)$ had lower $P_{\mathrm{N}}$ than those developing at warmer temperature $\left(25^{\circ} \mathrm{C}\right)($ El-Sharkawy et al. $1992 \mathrm{a}$, El-Sharkawy 2012).

Solar radiation is the most important factor determining photosynthesis performance which in turn affects growth and yield of plants. Different climatic zones have different light intensities which vary according to seasons (Khalifa 2011). Therefore, photosynthesis performance varied extensively depending on the amount and duration of light interception confounded by seasonal variations in temperature, rainfall, and other factors (Zhang et al. 2003). Photosynthesis capacity of plants can be assessed and compared using a $P_{\mathrm{N}} / I$ curve.-Cassava leaves of the same genotype developed in different climates responded differently to light intensity. Cassava plants (cv. M Col 1684) grown under the cool climate (mean annual temperature of $17^{\circ} \mathrm{C}$ and temperature range between $\left.12-22^{\circ} \mathrm{C}\right)$ had $P_{\mathrm{Nmax}}$ at $16 \mu \mathrm{mol}\left(\mathrm{CO}_{2}\right) \mathrm{m}^{-2} \mathrm{~s}^{-1}$ and light saturation point $\left(I_{\mathrm{sat}}\right)$ at $1,500 \mu \mathrm{mol}$ (photon) $\mathrm{m}^{-2} \mathrm{~s}^{-1}$ whereas those grown in warm climate (mean annual temperature of $24{ }^{\circ} \mathrm{C}$ and temperature range between $\left.17-30^{\circ} \mathrm{C}\right)$ had $P_{\mathrm{Nmax}}$ of $35 \mu \mathrm{mol}\left(\mathrm{CO}_{2}\right) \mathrm{m}^{-2} \mathrm{~s}^{-1}$ and $I_{\mathrm{sat}}$ at $1,800 \mu \mathrm{mol}\left(\right.$ photon) $\mathrm{m}^{-2} \mathrm{~s}^{-1}$ (El-Sharkawy et al. 1992a). Field-grown cassava plants were reported to have $I_{\text {sat }}$ higher than $1,800 \mu \mathrm{mol}$ (photon) $\mathrm{m}^{-2} \mathrm{~s}^{-1}$ and $P_{\mathrm{Nmax}}$ between 40-50 $\mu \mathrm{mol}\left(\mathrm{CO}_{2}\right) \mathrm{m}^{-2} \mathrm{~s}^{-1}$ (El-Sharkawy 2003), whereas the greenhouse-grown plants had lower $I_{\text {sat }}$ at 1,600 $\mu \mathrm{mol}\left(\right.$ photon) $\mathrm{m}^{-2} \mathrm{~s}^{-1}$ and $P_{\mathrm{Nmax}}$ at $22 \mu \operatorname{mol}\left(\mathrm{CO}_{2}\right) \mathrm{m}^{-2} \mathrm{~s}^{-1}$ (Pujol et al. 2008). Pignon et al. (2017) showed that $P_{\mathrm{Nmax}}$ of shaded leaves of a dense field-grown maize was $36 \%$ lower than that of the upper canopy leaves and the apparent quantum yield (AQE) of the shaded leaves $(0.041)$ was significantly lower than that of the sun leaves (0.048). Modeling canopy $\mathrm{CO}_{2}$ assimilation over diurnal courses suggested that the observed decline in AQE of the shaded leaves within canopy depth costs $10 \%$ of a potential canopy gain. The $P_{\mathrm{N}} / I$ curves of the upper, middle, and lower canopy leaves of Populus tremuloides grown under ambient $\left[343 \mu \mathrm{mol}\left(\mathrm{CO}_{2}\right) \mathrm{mol}^{-1}\right]$ and elevated [560 $\left.\mu \mathrm{mol}\left(\mathrm{CO}_{2}\right) \mathrm{mol}^{-1}\right] \mathrm{CO}_{2}$ demonstrated that elevated $\mathrm{CO}_{2}$ increased $P_{\mathrm{Nmax}}$ only in the upper (unshaded) leaves but did not benefit the middle and lower canopy leaves due to limited light intensity down the canopy and the reduction in Rubisco/N ratios due to both leaf position and elevated $\mathrm{CO}_{2}$ (Takeuchi et al. 2001). Variation in $P_{\mathrm{N}} / I$ curves have also been used to indicate photosynthesis performance of plants under different abiotic and biotic stress conditions including stresses from light (Heschel et al. 2004), nutrients (Lachapelle and Shipley 2012), competition (Gao et al. 2015), disease (Habermann et al. 2003), and pollution (Lin et al. 2015).

Photosynthetic performance of cassava grown under seasonally dry and hot humid climate of South America has been extensively studied (de Tafur et al. 1997, ElSharkawy and de Tafur 2007, El-Sharkawy 2012). However, detailed description of $P_{\mathrm{N}} / I$ curves in cassava 
under seasonal variations in the fields has not yet been addressed for the tropical savanna climate of Southeast Asia. Applying knowledge and performing research are seriously needed in real field situations with varying problems constraining agricultural productivity and environmental degradation (El-Sharkawy 2009b). Our objectives in this study were to acquire a better understanding of photosynthesis response to varying light intensity of a commercially important cassava (cv. Rayong 9;

\section{Materials and methods}

Study site: The experiment was conducted during April 2015 to May 2016 at the Field Crop Research Station at the Division of Agronomy, Faculty of Agriculture, Khon Kaen University $\left(16^{\circ} 47^{\prime} \mathrm{N}, 102^{\circ} 81^{\prime} \mathrm{E}, 195 \mathrm{~m}\right.$ a.s.l.). The soil texture was sandy loam (Oxic Paleustult) )Keeratikasikorn 1991(. The tropical savanna climate of Thailand can be divided into three seasons as follows: rainy season (June-October), cool season (NovemberFebruary), and hot season (March-May) (Thai Meteorological Department 2016). The cassava (Manihot esculenta Crantz) cultivar Rayong 9 (RY9), selected for this study, is widely grown in Thailand. Compared to other cultivars, it is outstanding for better growth, good plant type, wide adaptability to different regions in the country, and higher starch content suitable for ethanol production (Prammanee et al. 2010).

Weather condition and soil matric potential: The weather conditions at the study site were recorded by a
RY9) as affected by tropical climatic conditions in Thailand (in rainy, cool, and hot seasons) in an experimental field with and without irrigation (rain-fed). The data obtained was expected to provide information useful for designing agronomic practice with respect to water management and planting time in order to obtain optimum $\mathrm{CO}_{2}$ assimilation under tropical climate in the northeast of Thailand where $53.5 \%$ of cassava is being produced.

data logger model Watchdog 2700 (Watchdog, PCE group, PCE Germany, Meschede, Germany). Data were recorded during May 2015-May 2016 for temperature, relative humidity $(\mathrm{RH}), \mathrm{PAR}$, and rainfalls at intervals of $5 \mathrm{~min}$. The average monthly temperatures during the rainy, cool, and hot months were $28.0,25.2$, and $30.8^{\circ} \mathrm{C}$, respectively (Table 1). The coldest night temperatures were found in January $2016\left(9.2^{\circ} \mathrm{C}\right)$ and February 2016 $\left(8.0^{\circ} \mathrm{C}\right)$, and the hottest in April $2016\left(44.5^{\circ} \mathrm{C}\right)$. The average monthly RHs in the irrigated field varied from 51.7 (March 2016) to 95.7\% (August 2015) and in the rainfed conditions from 41.0 (March 2016) to $78.8 \%$ (August 2015 ) (Table 1). The maximum PAR at noon varied a great deal throughout the year (Fig. 1), being most intense in the hot season during May 2015/2016 [1,886/1,834 $\mu \mathrm{mol}\left(\right.$ photon) $\mathrm{m}^{-2} \mathrm{~s}^{-1}$, April 2016 [1,763 $\mu \mathrm{mol}$ (photon) $\mathrm{m}^{-2} \mathrm{~s}^{-1}$ ] and in the first month of rainy season in June 2015 $\left[1,904 \mu \mathrm{mol}\right.$ (photon) $\left.\mathrm{m}^{-2} \mathrm{~s}^{-1}\right]$. The number of hours of daylight was shortest in December 2015 (11 h) and longest

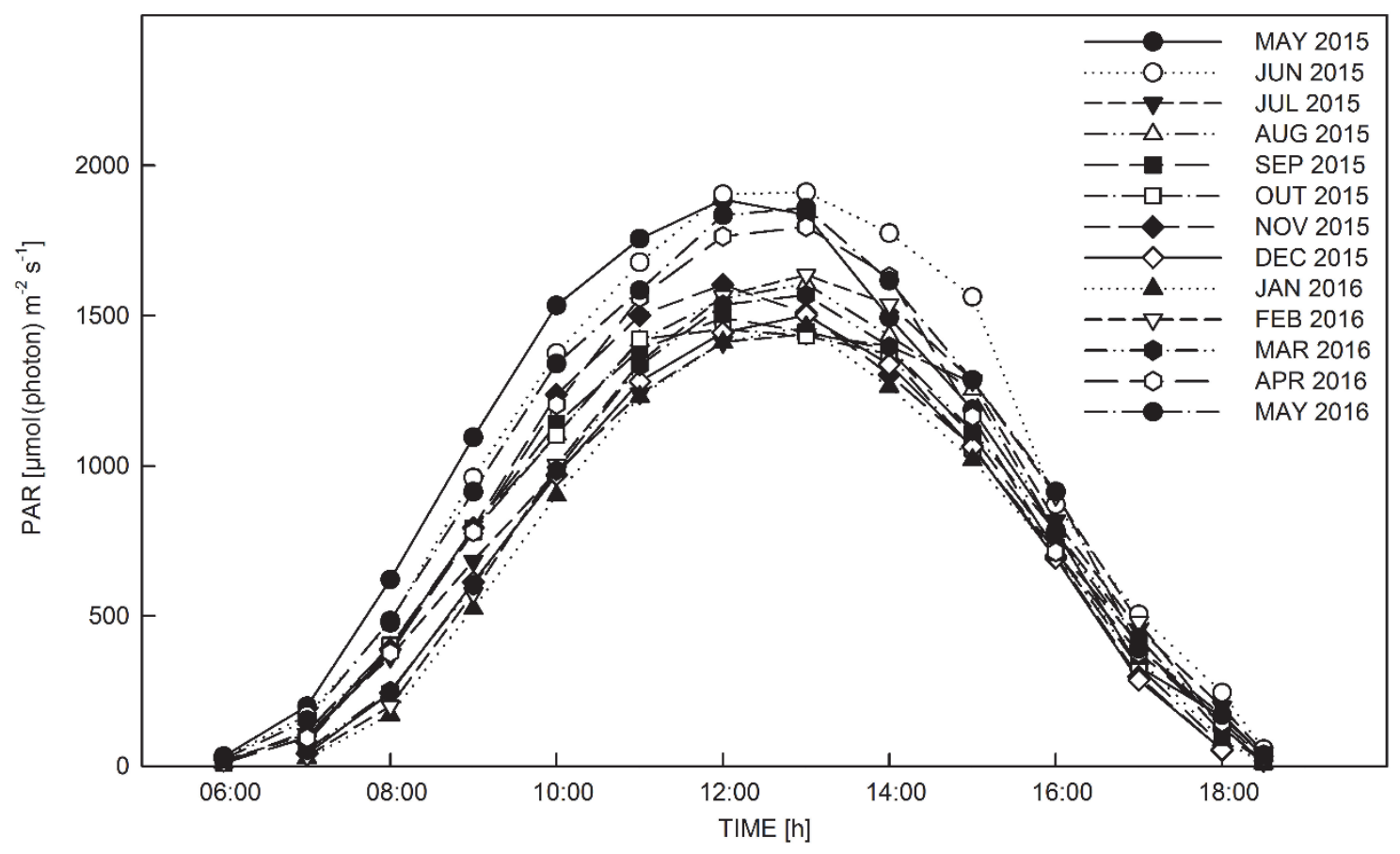

Fig. 1. Average hourly photosynthetically active radiation (PAR) during May 2015-May 2016 at the experimental site. 
in May 2015/2016 (12.50/12.75 h) (Table 1). The total precipitation during the entire growing season was $916.1 \mathrm{~mm}$. The seasonal rainfall and pan evaporation were as follows: $715.8 \mathrm{~mm}$ and $4.59 \mathrm{~mm}$ per day in the rainy season, $25.7 \mathrm{~mm}$ and $5.00 \mathrm{~mm}$ per day in the cool season, and $174.6 \mathrm{~mm}$ and $6.94 \mathrm{~mm}$ per day in the hot season. Soil matric potentials of the irrigated and rain-fed plots were monitored during the entire study period by using the watermark probe (Watchdog 1645, PCE group, PCE Germany, Meschede, Germany) placed at the depth of $20 \mathrm{~cm}$. The soil matric potentials at $20 \mathrm{~cm}$ depth in the irrigated plots were maintained well above $-30 \mathrm{kPa}$ below which irrigation was immediately supplied by a minisprinkler system. The average soil matric potential in the irrigated plots ranged between -3.44 (May 2016) to -16.03 (November 2015) kPa (Table 1). The rain-fed plots, on the other hand, experienced lower than $-30 \mathrm{kPa}$ during January-May 2016 (-39.85 to $-88.51 \mathrm{kPa})$.

Plant materials and culturing practices: Stem cuttings (20 cm in length) of cassava cv. RY9 were planted in ridges at $1 \times 1 \mathrm{~m}$ distance in the $5 \times 7 \mathrm{~m}$ plot with four replications in a randomized complete block design under irrigated and rain-fed conditions. During the first $30 \mathrm{~d}$ after planting, both irrigated and rain-fed plots were irrigated (using a mini-sprinkler system) to the level close to field capacity in order to enhance good crop establishment. After the first month, ample irrigation was applied only to the irrigated plots whereas the rain-fed plots remained without irrigation throughout the entire period of study. In the irrigated plots, irrigation was applied whenever the soil suction at $20 \mathrm{~cm}$ depth was lower than $-30 \mathrm{kPa}$ and water was supplied until the soil suction increased to $0 \mathrm{kPa}$. Manual weeding was practiced at one and two months after planting and fertilizers was applied according to the advice of Howeler (2002). In addition, the plants were regularly monitored for diseases and pests. Cassava were planted twice in the pre-rainy season, i.e., April (25 April 2015) and June (30 June 2015); and twice in the post-rainy season, i.e., November (10 November 2015) and December (15 December 2015).

Photosynthetic gas exchange: Data were collected from plants three and six months after planting (MAP). These stages of growth were selected for the study of photosynthesis performance because maximum vegetative growth and canopy development (leaf and stem growth) were achieved during this period (Alves 2002, Edet et al. 2015). In addition, storage roots begin to be formed at 2-3 MAP, and at $6 \mathrm{MAP}$, the maximum number of storage roots is attained and they start to bulk (Pellet and ElSharkawy 1993, Adjebeng-Danquah et al. 2016). However, Pellet and El-Sharkawy (1993), in two-year field trial, reported varietal differences (between four contrasting cultivars) in storage root formation early in the growth cycle. These authors stated that beyond 4 MAP, no apparent changes occurred in storage root number, with 
maximum number varied from 10 to 25 among cultivars. Photosynthesis of the plants 3 and 6 MAP was investigated in three different seasons (rainy, cool, and hot) in order to acquire some information on the effects of different environmental conditions prevailing in different seasons. Photosynthesis was measured on four randomly selected plants, one from each replication. For each plant, photosynthesis performance was investigated on the upper, middle, and lower canopy leaves. The measurements during the rainy season were performed during September-October 2015 using the 3-month-old June plants which had the average LAI of 3.7 and 2.7 for irrigated and rain-fed conditions, respectively, and the 6-month-old April plants (with average LAI of 4.4 and 4.1). For the cool season, photosynthesis was measured in December 2015 using the 6-month-old June plants (showing average LAI of 1.8 and 1.3 for irrigated and rainfed conditions, respectively), and in February 2016 on the 3-month-old November plants (having average LAI of 1.8 and 1.2). For the hot season, the measurements were performed in March 2016 on the 3-month-old December plants (showing average LAI of 1.4 and 1.1 for irrigated and rain-fed conditions, respectively), and in April 2016 on the 6-month-old November plants (showing average LAI of 5.7 and 2.7, respectively).

Photosynthesis performance was evaluated by constructing photosynthetic light-response $\left(P_{\mathrm{N}} / I\right)$ curves using a portable photosynthesis system (LI-6400XT, LI-COR, Lincoln, NE, USA) with standard $2 \times 3 \mathrm{~cm}$ leaf chamber, 6400-02B LED light source providing PAR of 2,500; 2,$000 ; 1,500 ; 1,000 ; 800,500,100,80,40$, and 0 $\mu \mathrm{mol}$ (photon) $\mathrm{m}^{-2} \mathrm{~s}^{-1}$. The humidity ranges inside the leaf chamber during the measurements were 36-89, 12-74, and $35-81 \%$ in the rainy, cool, and hot season, respectively. Measurements of leaf gas exchange also included stomatal conductance $\left(g_{\mathrm{s}}\right)$, and transpiration $(E)$. Water-use efficiency (WUE) was calculated as WUE $=P_{\mathrm{N}} / E$ (Ribeiro et al. 2009). The measurements were performed between 08:00-13:00 h, and the conditions during the measurement were set as follows: $400 \mu \mathrm{mol}\left(\mathrm{CO}_{2}\right) \mathrm{mol}^{-1}$, air flow rate of $500 \mu \mathrm{mol} \mathrm{s}{ }^{-1}$, block temperature of $30^{\circ} \mathrm{C}$, soil matric potential at $20 \mathrm{~cm}$ not less than $-30 \mathrm{kPa}$ (for irrigated treatment).

The response of leaf net photosynthetic rate $\left[P_{\mathrm{N}}\right.$,

\section{Results}

Photosynthetic light-response curve: In each season, leaves of the 3-month-old plants growing under full irrigation and rain-fed conditions showed differential responses to varying light intensity (Fig. 2). The parameters for each $P_{\mathrm{N}} / I$ curve including $P_{\mathrm{Nmax}}, R_{\mathrm{D}}, I_{\text {comp }}, I_{\text {sat }}$, and AQE are summarized in Table 2. The upper and middle canopy leaves of the irrigated plants maintained high photosynthetic capacity in all seasons showing insignificantly different $P_{\mathrm{Nmax}}$ values ranging from 26.51 to $30.95 \mu \mathrm{mol} \mathrm{m}{ }^{-2} \mathrm{~s}^{-1}$ (Fig. 2A,C,E; Table 2). Seasonal $\mu \operatorname{mol}\left(\mathrm{CO}_{2}\right) \mathrm{m}^{-2} \mathrm{~s}^{-1}$ ] to $I$ was modeled using the rectangular hyperbolic light-response curve model (Lobo et al. 2013):

$$
P_{\mathrm{N}}=\left[I \times P_{\mathrm{gmax}} /\left(I+I_{(50)}\right)\right]-R_{\mathrm{D}}
$$

where $P_{\text {gmax }}=$ maximum gross photosynthetic rate $\left[\mu \mathrm{mol}\left(\mathrm{CO}_{2}\right) \mathrm{m}^{-2} \mathrm{~s}^{-1}\right], I=$ photosynthetic photon flux density $\left[\mu \mathrm{mol}\left(\right.\right.$ photon) $\left.\mathrm{m}^{-2} \mathrm{~s}^{-1}\right], I_{(50)}=$ light-saturation point $\left[\mu \mathrm{mol}\right.$ (photon) $\mathrm{m}^{-2} \mathrm{~s}^{-1}$ ] at $P_{\mathrm{N}}+R_{\mathrm{D}}=0.5 P_{\text {gmax }}, R_{\mathrm{D}}=$ dark respiration rate $\left[\mu \mathrm{mol}\left(\mathrm{CO}_{2}\right) \mathrm{m}^{-2} \mathrm{~s}^{-1}\right]$. The lightcompensation point $\left(I_{\text {comp }}\right)$, maximum net photosynthetic rate $\left(P_{\mathrm{Nmax}}\right)$, and dark respiration rate $\left(R_{\mathrm{D}}\right)$ were estimated from the modeled light-response curve using the Solver function of Microsoft Excel in routines provided by Lobo et al. (2013). The apparent quantum yield (AQE) was calculated as the slope of the light curve at low light intensities and expressed in $\mu \mathrm{mol}\left(\mathrm{CO}_{2}\right) \mu \operatorname{mol}(\text { photon })^{-1}$.

\section{Predictions for year round net photosynthetic rates:} For each data set $\left(P_{\mathrm{N}}\right.$ at varying PAR of four leaves in three positions on the main stems of plants at 3 and 6 MAP measured in rainy, cool, and hot seasons under irrigated and rain-fed conditions), the $P_{\mathrm{N}} / I$ curve was constructed from the mean $P_{\mathrm{N}}$ at each PAR level. The nonlinear regression equations obtained from the curves were used to predict $P_{\mathrm{N}}$ the leaves could perform in response to the daily average PAR (data collected from the weather station during 1 June 2015-31 May 2016). The equations obtained from $P_{\mathrm{N}} / I$ curves in the rainy season were used to predict daily $P_{\mathrm{N}}$ during 1 June-31 October 2015, those in the cool season for 1 November 2015-28 February 2016, and those in the hot season for 1 March-31 May 2016. The average daily PAR (data from the weather station) was used to predict daily $P_{\mathrm{N}}$ of the upper canopy leaves. However, for the middle and lower canopy leaves, the PAR values used to predict daily $P_{\mathrm{N}}$ were calculated from percent light transmission (relative to PAR at the upper leaf position, Fig. 7S - supplement available online) at each level as determined by line quantum sensor (Licor-191).

Data analysis: Analysis of variance (ANOVA) and Duncan's multiple range test was used to compare means using a MSTAT-C version 1.42 program (Freed and Nissen 1992). All statistical analyses were carried out following the procedure described by Gomez and Gomez (1984).

variation in photosynthetic capacity was, however, observed in the rain-fed plants. The $P_{\text {Nmax }}$ values of the upper and middle canopy leaves of the rain-fed plants measured during the cool [18.05 and $23.58 \mu \mathrm{mol}\left(\mathrm{CO}_{2}\right)$ $\left.\mathrm{m}^{-2} \mathrm{~s}^{-1}\right]$ and hot $\left[23.33\right.$ and $\left.23.15 \mu \mathrm{mol}\left(\mathrm{CO}_{2}\right) \mathrm{m}^{-2} \mathrm{~s}^{-1}\right]$ seasons were significantly lower than those measured during the rainy season [30.26 and $30.70 \mu \mathrm{mol}\left(\mathrm{CO}_{2}\right) \mathrm{m}^{-2} \mathrm{~s}^{-1}$ ] (Fig. 2B,D,F; Table 2). Photosynthetic capacity of the lower canopy leaves was much reduced compared to the upper-position leaves and the percentage reductions varied 


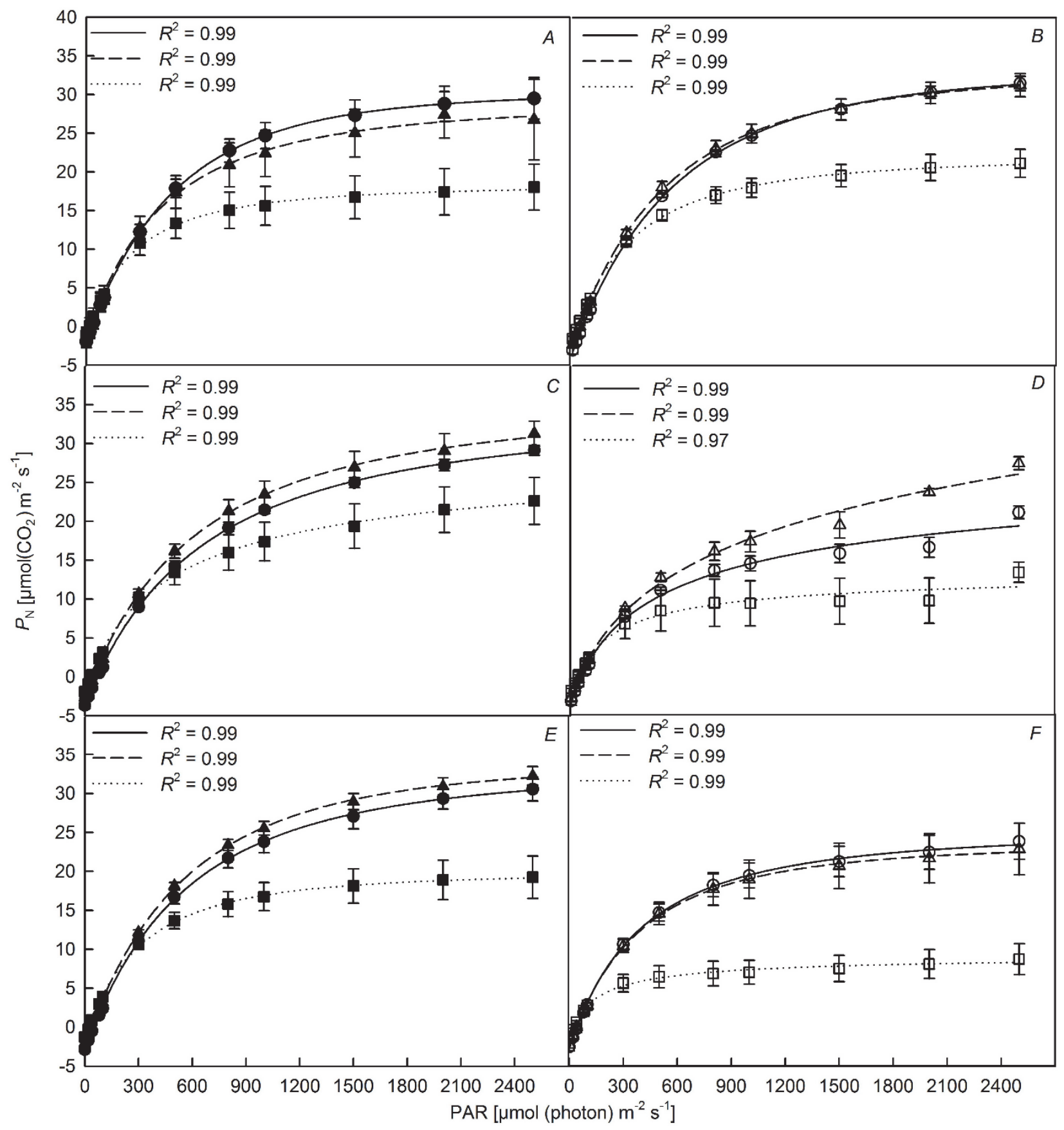

Fig. 2. Net photosynthetic rate $\left(P_{\mathrm{N}}\right) v s$. light intensity of 3-month-old cassava cv. RY9 grown under irrigated $(A, C, E$; close symbols $)$ and rain-fed $(B, D, F$; open symbols) conditions in rainy $(A, B)$, cool $(C, D)$ and hot $(E, F)$ season. Photosynthesis measurement was performed on the upper (solid line), middle (dashed line), and lower (dotted line) canopy of the same plant. Means \pm SE of four replicates.

with water regimes and seasons. For irrigated plants, the $P_{\text {Nmax }}$ values of the lower leaves were reduced from the upper canopy leaves by 38,26 , and $38 \%$ during rainy (Fig. $2 A$ ), cool (Fig. 2C), and hot (Fig. 2E) seasons, respectively, while the corresponding values for the rain-fed plants were 34 (Fig. 2B), 53 (Fig. 2D), and 63\% (Fig. 2F). During rainy season, photosynthetic capacity of the leaves at each canopy position was not significantly different between the irrigated and rain-fed plants (Fig. 2A,B; Table 2). However, the $P_{\text {Nmax }}$ values of the rain-fed were significantly lower than those of the irrigated plants during the cool (Fig. 2C,D; Table 2) and hot (Fig. 2E,F; Table 2) seasons; the reduction being the greatest (approximately $50 \%$ ) in the lower canopy leaves. 
Table 2. The variables calculated from the rectangular hyperbola Michaelis-Menten-based models (Lobo et al. 2013) to fit the net photosynthetic light-response curves: maximum net photosynthetic rate $\left(P_{\mathrm{Nmax}}\right)$, dark respiration rate $\left(R_{\mathrm{D}}\right)$, light-compensation point $\left(I_{\text {comp }}\right)$, and saturation irradiance values $\left(I_{\text {sat }}\right)$. Apparent quantum yield $(\mathrm{AQE})$ is the slope of the light curve at low light intensities. The photosynthetic light-response curves were determined from cassava cv. RY9 at plant age three months after planting (MAP) under irrigated and rain-fed conditions in rainy, cool, and hot season. Different letters indicate significant differences at $P<0.05$ according to Duncan's multiple range test.

\begin{tabular}{|c|c|c|c|c|c|c|c|c|c|c|}
\hline \multirow[t]{2}{*}{$3 \mathrm{MAP}$} & & \multicolumn{3}{|c|}{ Rainy season } & \multicolumn{3}{|c|}{ Cool season } & \multicolumn{3}{|c|}{ Hot season } \\
\hline & & Top & Middle & Lower & Top & Middle & Lower & Top & Middle & Lower \\
\hline $\begin{array}{l}P_{\mathrm{Nmax}} \\
{\left[\mu \operatorname{mol}\left(\mathrm{CO}_{2}\right) \mathrm{m}^{-2} \mathrm{~s}^{-1}\right]}\end{array}$ & $\begin{array}{l}\text { Irrigated } \\
\text { Rain-fed }\end{array}$ & $\begin{array}{l}28.83^{\mathrm{a}} \\
30.26^{\mathrm{a}}\end{array}$ & $\begin{array}{l}26.51^{\mathrm{abc}} \\
30.70^{\mathrm{a}}\end{array}$ & $\begin{array}{l}17.51^{\mathrm{d}} \\
20.64^{\mathrm{cd}}\end{array}$ & $\begin{array}{l}27.23^{\mathrm{abc}} \\
18.05^{\mathrm{d}}\end{array}$ & $\begin{array}{l}29.27^{\mathrm{ab}} \\
23.58^{\mathrm{bcd}}\end{array}$ & $\begin{array}{l}21.22^{\mathrm{cd}} \\
11.18^{\mathrm{e}}\end{array}$ & $\begin{array}{l}29.67^{\mathrm{ab}} \\
23.33^{\mathrm{bcd}}\end{array}$ & $\begin{array}{l}30.95^{\mathrm{a}} \\
23.15^{\mathrm{bcd}}\end{array}$ & $\begin{array}{l}18.98^{\mathrm{d}} \\
8.95^{\mathrm{e}}\end{array}$ \\
\hline $\begin{array}{l}R_{\mathrm{D}} \\
{\left[\mu \mathrm{mol}\left(\mathrm{CO}_{2}\right) \mathrm{m}^{-2} \mathrm{~s}^{-1}\right]}\end{array}$ & $\begin{array}{l}\text { Irrigated } \\
\text { Rain-fed }\end{array}$ & $\begin{array}{l}3.388^{\mathrm{abc}} \\
3.670^{\mathrm{ab}}\end{array}$ & $\begin{array}{l}3.045^{\mathrm{a}-\mathrm{e}} \\
2.997^{\mathrm{a}-\mathrm{e}}\end{array}$ & $\begin{array}{l}2.487^{\mathrm{c}-\mathrm{f}} \\
1.982^{\mathrm{efg}}\end{array}$ & $\begin{array}{l}3.850^{\mathrm{a}} \\
3.125^{\mathrm{a}-\mathrm{d}}\end{array}$ & $\begin{array}{l}3.025^{\mathrm{a}-\mathrm{e}} \\
2.375^{\mathrm{c}-\mathrm{g}}\end{array}$ & $\begin{array}{l}2.050^{\mathrm{d}-\mathrm{g}} \\
1.975^{\mathrm{efg}}\end{array}$ & $\begin{array}{l}3.175^{\mathrm{abc}} \\
3.200^{\mathrm{abc}}\end{array}$ & $\begin{array}{l}2.700^{\mathrm{b}-\mathrm{f}} \\
3.000^{\mathrm{a}-\mathrm{e}}\end{array}$ & $\begin{array}{l}1.775^{\mathrm{fg}} \\
1.375^{\mathrm{g}}\end{array}$ \\
\hline $\begin{array}{l}I_{\text {comp }} \\
{\left[\mu \mathrm{mol}(\text { photon }) \mathrm{m}^{-2} \mathrm{~s}^{-1}\right]}\end{array}$ & $\begin{array}{l}\text { Irrigated } \\
\text { Rain-fed }\end{array}$ & $\begin{array}{l}43.27^{\mathrm{cde}} \\
52.15^{\mathrm{bc}}\end{array}$ & $\begin{array}{l}40.00^{\mathrm{c}-\mathrm{f}} \\
38.31^{\mathrm{c}-\mathrm{f}}\end{array}$ & $\begin{array}{l}32.03^{\mathrm{e}-\mathrm{h}} \\
25.84^{\text {fgh }}\end{array}$ & $\begin{array}{l}67.85^{\mathrm{a}} \\
59.35^{\mathrm{ab}}\end{array}$ & $\begin{array}{l}48.17^{\mathrm{bcd}} \\
49.97^{\mathrm{bc}}\end{array}$ & $\begin{array}{l}33.20^{\mathrm{d}-\mathrm{h}} \\
39.33^{\mathrm{c}-\mathrm{f}}\end{array}$ & $\begin{array}{l}47.60^{\mathrm{b}-\mathrm{e}} \\
44.90^{\mathrm{b}-\mathrm{e}}\end{array}$ & $\begin{array}{l}36.95^{\mathrm{c}-\mathrm{g}} \\
39.85^{\mathrm{c}-\mathrm{f}}\end{array}$ & $\begin{array}{l}22.98^{\mathrm{gh}} \\
18.67^{\mathrm{h}}\end{array}$ \\
\hline $\begin{array}{l}\mathrm{AQE} \\
{\left[\mu \mathrm{mol}\left(\mathrm{CO}_{2}\right) \mu \mathrm{mol}(\text { photon })^{-1}\right]}\end{array}$ & $\begin{array}{l}\text { Irrigated } \\
\text { Rain-fed }\end{array}$ & $\begin{array}{l}0.0541 \\
0.0528\end{array}$ & $\begin{array}{l}0.0531 \\
0.0565\end{array}$ & $\begin{array}{l}0.0504 \\
0.0525\end{array}$ & $\begin{array}{l}0.0490 \\
0.0460\end{array}$ & $\begin{array}{l}0.0501 \\
0.0485\end{array}$ & $\begin{array}{l}0.0515 \\
0.0428\end{array}$ & $\begin{array}{l}0.0523 \\
0.0543\end{array}$ & $\begin{array}{l}0.0520 \\
0.0516\end{array}$ & $\begin{array}{l}0.0522 \\
0.0417\end{array}$ \\
\hline $\begin{array}{l}I_{\text {sat }} \\
{\left[\mu \operatorname{mol}(\text { photon}) \mathrm{m}^{-2} \mathrm{~s}^{-1}\right]}\end{array}$ & $\begin{array}{l}\text { Irrigated } \\
\text { Rain-fed }\end{array}$ & $\begin{array}{l}>1,800 \\
>2,000\end{array}$ & $\begin{array}{l}>1,800 \\
>1,800\end{array}$ & $\begin{array}{l}>1,100 \\
>1,500\end{array}$ & $\begin{array}{l}>2,200 \\
>1,600\end{array}$ & $\begin{array}{l}>2,200 \\
>2,100\end{array}$ & $\begin{array}{l}>1,600 \\
>700\end{array}$ & $\begin{array}{l}>2,000 \\
>1,700\end{array}$ & $\begin{array}{l}>2,000 \\
>1,400\end{array}$ & $\begin{array}{l}>1,200 \\
>700\end{array}$ \\
\hline
\end{tabular}

The $I_{\text {sat }}$ values (Table 2) were higher in the upper and middle canopy leaves than those of the lower ones. The $I_{\text {sat }}$ of the upper and middle canopy leaves of the irrigated plants were similar in all seasons. However, in the rain-fed plants, $I_{\text {sat }}$ of the upper were higher than that of the middle canopy leaves in rainy and hot seasons, while the reverse trend was observed in the cool season. At the same leaf position, the irrigated had higher $I_{\text {sat }}$ than the rain-fed plants except for those in the rainy season.

The $I_{\text {comp }}$ generally decreased from upper to lower canopy leaves (Table 2). The $I_{\text {comp }}$ values in all cases did not differ between the irrigated and rain-fed plants. However, seasonal variation was observed in that the $I_{\text {comp }}$ values during the cool season tended to be higher than those in the rainy and hot seasons. The maximum $I_{\text {comp }}$ [67.85 $\mu$ mol(photon) $\left.\mathrm{m}^{-2} \mathrm{~s}^{-1}\right]$ was recorded in the top canopy leaves of the irrigated plants during the cool season and the minimum $\left[18.67 \mu\right.$ mol(photon) $\left.\mathrm{m}^{-2} \mathrm{~s}^{-1}\right]$ was in the lower canopy leaves of rain-fed plants during the hot season.

The $R_{\mathrm{D}}$ decreased from the top to the lower canopy leaves (Table 2). In general, $R_{\mathrm{D}}$ values of the lower canopy were lower, but not significantly different from those of the middle canopy leaves, but differed significantly from those of the upper canopy leaves. Similar to $I_{\text {comp }}$, the maximum $R_{\mathrm{D}}$ [3.85 $\left.\mu \mathrm{mol}\left(\mathrm{CO}_{2}\right) \mathrm{m}^{-2} \mathrm{~s}^{-1}\right]$ was recorded in the top canopy leaves of the irrigated plants during the cool season while the minimum $\left[1.37 \mu \mathrm{mol}\left(\mathrm{CO}_{2}\right) \mathrm{m}^{-2} \mathrm{~s}^{-1}\right]$ was in the lower canopy leaves of rain-fed plants during the hot season.

No significant differences were observed in AQE between the plants in different seasons, water regimes, and leaf positions, which were ranging from $0.0565-0.0417$ $\mu \mathrm{mol}\left(\mathrm{CO}_{2}\right) \mu \mathrm{mol}^{-1}$ (photon). However, it was observed that leaves of the rain-fed plants during the cool season tended to have lower $\mathrm{AQE}$ values than the remaining plants.

The $P_{\mathrm{N}} / I$ curve of the 6-month-old plants varied among water regimes, seasons, and leaf positions (Fig. 3, Table 3). In each season, photosynthetic capacity, as indicated by the $P_{\mathrm{Nmax}}$ values of the leaves at each position, did not significantly differ between the two water regimes (Fig. 3). The $P_{\text {Nmax }}$ values of the upper and middle canopy leaves for each water regime in each season were not significantly different (except for the rain-fed plants in the hot season). The maximum $P_{\mathrm{Nmax}}$ was recorded in the upper canopy leaves of the rain-fed plants during the rainy season $\left[30.60 \mu \mathrm{mol}\left(\mathrm{CO}_{2}\right) \mathrm{m}^{-2} \mathrm{~s}^{-1}\right.$ in Fig. $\left.3 B\right]$, while the minimum was found in the lower canopy leaves of the irrigated plants during the hot season $\left[7.50 \mu \mathrm{mol}\left(\mathrm{CO}_{2}\right) \mathrm{m}^{-2} \mathrm{~s}^{-1}\right.$ in Fig. $3 F]$. Seasonal variation in photosynthetic capacity was observed in both irrigated and rain-fed plants. The $P_{\text {Nmax }}$ values at each leaf position in the rainy season were significantly higher than those in the cool and hot seasons. For irrigated plants, percentage reductions in $P_{\mathrm{Nmax}}$ (in comparison to the values in the rainy season in Fig. $3 A$ ) were 30,38 , and $39 \%$ in the cool (Fig. 3C), 22, 33, and $43 \%$ in the hot season (Fig. $3 E$ ) for upper, middle, and lower canopy leaves, respectively. The corresponding percentage reductions for rain-fed plants were 44,47 , and $50 \%$ in the cool (Fig. 3D), and 32, 49, and 55\% in the hot season (Fig. $3 F$ ). The $P_{\text {Nmax }}$ values of the lower canopy leaves were all significantly lower than those of the upper/middle canopy leaves. For irrigated plants, the $P_{\mathrm{Nmax}}$ values of the lower canopy leaves were reduced (in comparison to the values in the upper canopy leaves) by 54,60 , and $66 \%$ during rainy, cool, and hot seasons, respectively, while the corresponding figures for the rainfed plants were 43,50 , and $62 \%$. 


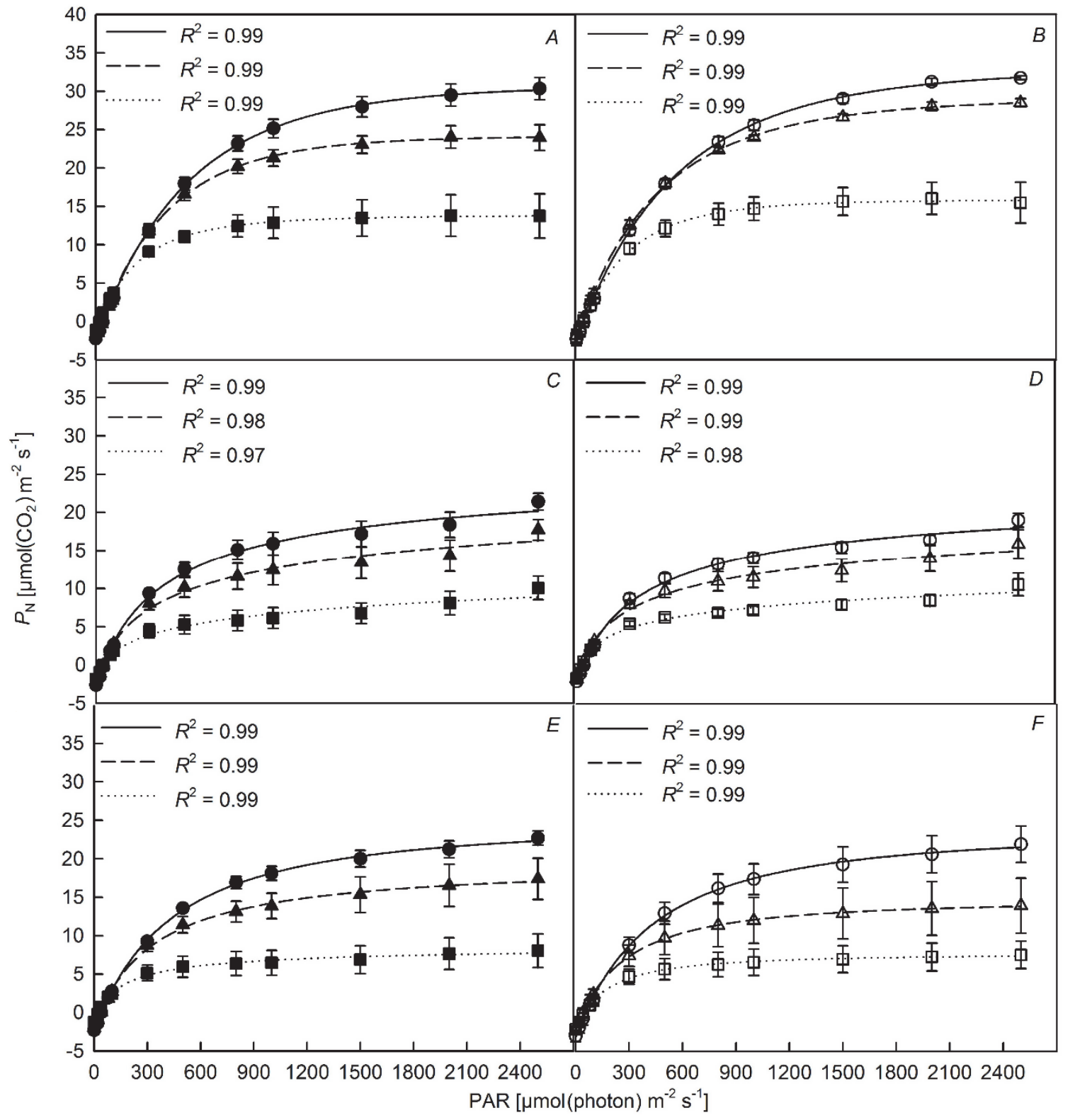

Fig. 3. Net photosynthetic rate $\left(P_{\mathrm{N}}\right) v s$. light intensity of 6-month-old cassava cv. RY9 grown under irrigated (A,C,E; close symbols) and rainfed $(B, D, F$; open symbols) conditions in rainy $(A, B)$, cool $(C, D)$ and hot $(E, F)$ season. Photosynthesis measurement was performed on the upper (solid line), middle (dashed line), and lower (dotted line) canopy of the same plant. Means \pm SE of four replicates.

Similar to the 3-month-old plants, the $I_{\text {sat }}$ values in the 6-month-old plants (Table 3) were higher in the upper and middle canopy leaves than that of the lower ones. At the same leaf position, the irrigated had similar or higher $I_{\text {sat }}$ than that of the rain-fed plants in most cases, except for the upper and lower leaves in the rainy season where the rainfed had higher $I_{\text {sat }}$ than the irrigated plants.

The $I_{\text {comp }}$ generally decreased from upper to lower canopy leaves (Table 3 ). The $I_{\text {comp }}$ values in all cases did not differ between the irrigated and rain-fed plants (except for the upper canopy leaves in the hot season). Among irrigated plants, $I_{\text {comp }}$ values for each leaf position did not vary among different seasons. However, for rain-fed plants, $I_{\text {comp }}$ tended to be highest in the hot season. The maximum $I_{\text {comp }}\left[65.35 \mu \mathrm{mol}\right.$ (photon) $\left.\mathrm{m}^{-2} \mathrm{~s}^{-1}\right]$ was recorded in the upper canopy leaves of the rain-fed plants during the hot and the minimum $\left[10.03 \mu \mathrm{mol}\left(\right.\right.$ photon) $\left.\mathrm{m}^{-2} \mathrm{~s}^{-1}\right]$ in the rain-fed lower canopy leaves in the rainy season.

The $R_{\mathrm{D}}$ decreased from the upper to the lower canopy leaves (Table 3). In all cases, no significant differences in $R_{\mathrm{D}}$ were observed between the irrigated and the rain-fed plants (except for the upper canopy leaves in the hot season). In general, at each leaf position, $R_{\mathrm{D}}$ of the 6month-old plants were lower than those of the 3-month-old 
Table 3. The variables calculated from the rectangular hyperbola Michaelis-Menten-based models (Lobo et al. 2013) to fit the net photosynthetic light-response curves: maximum net photosynthetic rate $\left(P_{\mathrm{Nmax}}\right)$, dark respiration rate $\left(R_{\mathrm{D}}\right)$, light-compensation point $\left(I_{\text {comp }}\right)$, and saturation irradiance values $\left(I_{\text {sat }}\right)$. Apparent quantum yield $(\mathrm{AQE})$ is the slope of the light curve at low light intensities. The photosynthetic light-response curves were determined from cassava cv. RY9 at plant age six months after planting (MAP) under irrigated and rain-fed conditions in rainy, cool and hot season. Different letters indicate significant differences at $P<0.05$ according to Duncan's multiple range test.

\begin{tabular}{|c|c|c|c|c|c|c|c|c|c|c|}
\hline \multirow[t]{2}{*}{ 6MAP } & & \multicolumn{3}{|c|}{ Rainy season } & \multicolumn{3}{|c|}{ Cool season } & \multicolumn{3}{|c|}{ Hot season } \\
\hline & & Top & Middle & Lower & Top & Middle & Lower & Top & Middle & Lower \\
\hline $\begin{array}{l}P_{\mathrm{Nmax}} \\
{\left[\mu \operatorname{mol}\left(\mathrm{CO}_{2}\right) \mathrm{m}^{-2} \mathrm{~s}^{-1}\right]}\end{array}$ & $\begin{array}{l}\text { Irrigated } \\
\text { Rainfed }\end{array}$ & $\begin{array}{l}27.55^{\mathrm{ab}} \\
30.60^{\mathrm{a}}\end{array}$ & $\begin{array}{l}24.48^{\mathrm{bcd}} \\
26.55^{\mathrm{abc}}\end{array}$ & $\begin{array}{l}13.07^{\mathrm{g}-\mathrm{j}} \\
17.60^{\mathrm{efg}}\end{array}$ & $\begin{array}{l}19.10^{\text {ef }} \\
17.08^{\text {efg }}\end{array}$ & $\begin{array}{l}15.13^{\mathrm{fg}} \\
14.00^{\mathrm{fgh}}\end{array}$ & $\begin{array}{l}8.025^{\mathrm{jk}} \\
8.80^{\mathrm{h}-\mathrm{k}}\end{array}$ & $\begin{array}{l}21.47^{\text {cde }} \\
20.92^{\text {de }}\end{array}$ & $\begin{array}{l}16.48^{\text {efg }} \\
13.53^{f-i}\end{array}$ & $\begin{array}{l}7.50^{\mathrm{k}} \\
8.27^{\mathrm{ijk}}\end{array}$ \\
\hline $\begin{array}{l}R_{\mathrm{D}} \\
{\left[\mu \mathrm{mol}\left(\mathrm{CO}_{2}\right) \mathrm{m}^{-2} \mathrm{~s}^{-1}\right]}\end{array}$ & $\begin{array}{l}\text { Irrigated } \\
\text { Rainfed }\end{array}$ & $\begin{array}{l}2.475^{\mathrm{bcd}} \\
2.450^{\mathrm{bcd}}\end{array}$ & $\begin{array}{l}1.525^{\mathrm{def}} \\
1.575^{\mathrm{c}-\mathrm{f}}\end{array}$ & $\begin{array}{l}1.875^{\mathrm{b}-\mathrm{f}} \\
0.8250^{\mathrm{f}}\end{array}$ & $\begin{array}{l}2.725^{\mathrm{b}} \\
2.200^{\mathrm{b}-\mathrm{e}}\end{array}$ & $\begin{array}{l}2.025^{\mathrm{b}-\mathrm{e}} \\
1.625^{\mathrm{b}-\mathrm{f}}\end{array}$ & $\begin{array}{l}1.650^{\mathrm{b}-\mathrm{f}} \\
1.325^{\mathrm{ef}}\end{array}$ & $\begin{array}{l}2.600^{\text {bcd }} \\
3.875^{\mathrm{a}}\end{array}$ & $\begin{array}{l}2.250^{\mathrm{b}-\mathrm{e}} \\
2.675^{\mathrm{bc}}\end{array}$ & $\begin{array}{l}1.300^{\mathrm{ef}} \\
2.400^{\mathrm{b}-\mathrm{e}}\end{array}$ \\
\hline $\begin{array}{l}I_{\text {comp }} \\
{\left[\mu \mathrm{mol}(\text { photon }) \mathrm{m}^{-2} \mathrm{~s}^{-1}\right]}\end{array}$ & $\begin{array}{l}\text { Irrigated } \\
\text { Rainfed }\end{array}$ & $\begin{array}{l}37.63^{\text {bcd }} \\
28.48^{\text {bee }}\end{array}$ & $\begin{array}{l}20.38^{\mathrm{de}} \\
19.15^{\mathrm{de}}\end{array}$ & $\begin{array}{l}21.10^{\mathrm{de}} \\
10.03^{\mathrm{e}}\end{array}$ & $\begin{array}{l}42.30^{\mathrm{b}} \\
38.88^{\mathrm{bcd}}\end{array}$ & $\begin{array}{l}37.85^{\mathrm{bcd}} \\
28.40^{\mathrm{b}-\mathrm{e}}\end{array}$ & $\begin{array}{l}43.40^{\mathrm{b}} \\
28.30^{\mathrm{b}-\mathrm{e}}\end{array}$ & $\begin{array}{l}41.22^{\mathrm{bc}} \\
65.35^{\mathrm{a}}\end{array}$ & $\begin{array}{l}35.97^{\mathrm{bcd}} \\
41.28^{\mathrm{bc}}\end{array}$ & $\begin{array}{l}21.77^{\text {cde }} \\
45.15^{\mathrm{b}}\end{array}$ \\
\hline $\begin{array}{l}\mathrm{AQE} \\
{\left[\mu \mathrm{mol}\left(\mathrm{CO}_{2}\right) \mu \mathrm{mol}^{-1} \text { (photon) }\right]}\end{array}$ & $\begin{array}{l}\text { Irrigated } \\
\text { Rainfed }\end{array}$ & $\begin{array}{l}0.0469^{\mathrm{abc}} \\
0.0582^{\mathrm{a}}\end{array}$ & $\begin{array}{l}0.0534^{\mathrm{abc}} \\
0.0579^{\mathrm{a}}\end{array}$ & $\begin{array}{l}0.0488^{\mathrm{abc}} \\
0.0556^{\mathrm{ab}}\end{array}$ & $\begin{array}{l}0.0528^{\mathrm{abc}} \\
0.0478^{\mathrm{abc}}\end{array}$ & $\begin{array}{l}0.0484^{\mathrm{abc}} \\
0.0490^{\mathrm{abc}}\end{array}$ & $\begin{array}{l}0.0372^{\mathrm{c}} \\
0.0426^{\mathrm{abc}}\end{array}$ & $\begin{array}{l}0.0516^{\text {abc }} \\
0.0478^{\mathrm{abc}}\end{array}$ & $\begin{array}{l}0.0464^{\mathrm{abc}} \\
0.0471^{\mathrm{abc}}\end{array}$ & $\begin{array}{l}0.0367^{\mathrm{c}} \\
0.0390^{\mathrm{bc}}\end{array}$ \\
\hline $\begin{array}{l}I_{\text {sat }} \\
{\left[\mu \mathrm{mol}(\text { photon}) \mathrm{m}^{-2} \mathrm{~s}^{-1}\right]}\end{array}$ & $\begin{array}{l}\text { Irrigated } \\
\text { Rainfed }\end{array}$ & $\begin{array}{l}>2,000 \\
>2,100\end{array}$ & $\begin{array}{l}>1,800 \\
>1,800\end{array}$ & $\begin{array}{l}>800 \\
>1,000\end{array}$ & $\begin{array}{l}>1,600 \\
>1,600\end{array}$ & $\begin{array}{l}>1,600 \\
>1,400\end{array}$ & $\begin{array}{l}>600 \\
>700\end{array}$ & $\begin{array}{l}>1,700 \\
>1,600\end{array}$ & $\begin{array}{l}>1,600 \\
>1,000\end{array}$ & $\begin{array}{l}>600 \\
>500\end{array}$ \\
\hline
\end{tabular}

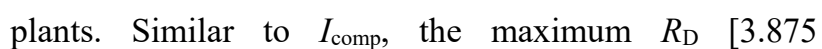
$\mu \mathrm{mol}\left(\mathrm{CO}_{2}\right) \mathrm{m}^{-2} \mathrm{~s}^{-1}$ ] was recorded in the upper canopy leaves of the rain-fed plants during the hot season while the minimum $\left[0.825 \mu \mathrm{mol}\left(\mathrm{CO}_{2}\right) \mathrm{m}^{-2} \mathrm{~s}^{-1}\right]$ was in the lower canopy leaves of the rain-fed plants in the rainy season.

The AQE of the 6-month-old plants showed more variation than those of the 3-month-old plants showing the values in the range of $0.0367-0.0582 \mu \operatorname{mol}\left(\mathrm{CO}_{2}\right)$ $\mu$ mol(photon $)^{-1}$. Leaves of the rain-fed plants in the rainy season had the maximum AQE, while the lower canopy leaves of the plants growing in the cool and hot seasons tended to have low AQE.

In addition to $P_{\mathrm{N}} / I$ curves, light-response curves of related parameters were recorded and displayed as supplemented data. Light-response changes in $g_{\mathrm{s}}, E$, and WUE as a function of PAR in the three seasons are illustrated in Figs. 1S, 2S, 3S (supplements available online) for the 3-month-old plants, and Figs. 4S, 5S, 6S (supplements available online) for the 6-month-old plants.

Predictions for year round net photosynthetic rates: The nonlinear regression equations of each $P_{\mathrm{N}} / I$ curve which were used to predict photosynthetic rates in rainy, cool, and hot seasons of cassava at two plant ages (three and six months) under irrigated and rain-fed conditions are shown in Table 4 . The predicted daily net photosynthetic rates throughout the year (1 June, 2015-31 May 2016) of

\section{Discussion}

Seasonal variation in photosynthesis performance of cassava based on the response to light intensity was apparent for the plants grown under both irrigated and rainfed conditions, particularly in the 6-month-old plants (Fig. 3). In the 3-month-old plants, seasonal variation in cassava leaves are demonstrated in Fig. 4. For the 3-month-old plants in the rainy season, the average predicted photosynthetic rates of the upper, middle, and lower canopy leaves under the rain-fed [23.4, 15.8, and $9.8 \mu \mathrm{mol}\left(\mathrm{CO}_{2}\right) \mathrm{m}^{-2} \mathrm{~s}^{-1}$ ] were higher than those under the irrigated $\left[21.9,14.9\right.$, and $\left.9.6 \mu \operatorname{mol}\left(\mathrm{CO}_{2}\right) \mathrm{m}^{-2} \mathrm{~s}^{-1}\right]$ conditions (Table $2 \mathrm{~S}$ - supplement available online). In contrast, in the cool and hot seasons, the upper, middle, and lower canopy leaves under irrigation [cool season: 16.6, 15.0, and $10.2 \mu \mathrm{mol}\left(\mathrm{CO}_{2}\right) \mathrm{m}^{-2} \mathrm{~s}^{-1}$; hot season: 22.7 , 19.2, and $11.1 \mu \mathrm{mol}\left(\mathrm{CO}_{2}\right) \mathrm{m}^{-2} \mathrm{~s}^{-1}$ ] had higher rates of net photosynthesis than that under rain-fed [cool season: 13.7, 13.1, and $6.8 \mu \mathrm{mol}\left(\mathrm{CO}_{2}\right) \mathrm{m}^{-2} \mathrm{~s}^{-1}$; hot season: 18.9, 16.2, and $6.0 \mu \mathrm{mol}\left(\mathrm{CO}_{2}\right) \mathrm{m}^{-2} \mathrm{~s}^{-1}$ ] conditions (Fig. 4A,C,E; Table 2S). For the 6-month-old plants, the predicted average photosynthetic rates of the upper canopy leaves in the rainy season under the rain-fed $\left[25.1 \mu \mathrm{mol}\left(\mathrm{CO}_{2}\right) \mathrm{m}^{-2} \mathrm{~s}^{-1}\right]$ was higher than that of the irrigated $\left[23.8 \mu \mathrm{mol}\left(\mathrm{CO}_{2}\right) \mathrm{m}^{-2} \mathrm{~s}^{-1}\right]$ plants. In contrast, in the cool and hot seasons, the upper canopy leaves under irrigation [cool season: 15.4 $\mu \mathrm{mol}\left(\mathrm{CO}_{2}\right) \mathrm{m}^{-2} \mathrm{~s}^{-1}$, hot season: $\left.17.8 \mu \mathrm{mol}\left(\mathrm{CO}_{2}\right) \mathrm{m}^{-2} \mathrm{~s}^{-1}\right]$ had higher photosynthetic rates than those under rain-fed [cool season: $13.7 \mu \mathrm{mol}\left(\mathrm{CO}_{2}\right) \mathrm{m}^{-2} \mathrm{~s}^{-1}$; hot season: 17.1 $\mu \mathrm{mol}\left(\mathrm{CO}_{2}\right) \mathrm{m}^{-2} \mathrm{~s}^{-1}$ ] conditions (Fig. 4B; Table 2S). However, for the middle and lower canopy leaves, higher photosynthetic rates were predicted for the rain-fed conditions throughout the year (Fig. 4D,F; Table 2S).
$P_{\text {Nmax }}$ was found only in the rain-fed plants (Fig. 2, Table 2). In the rainy season, similar $P_{\text {Nmax }}$ were recorded between the irrigated and rain-fed plants due to high soil moisture (no less than $-30 \mathrm{kPa}$ or close to field capacity in both water regimes) as well as high $\mathrm{RH}$, high rainfalls, and 


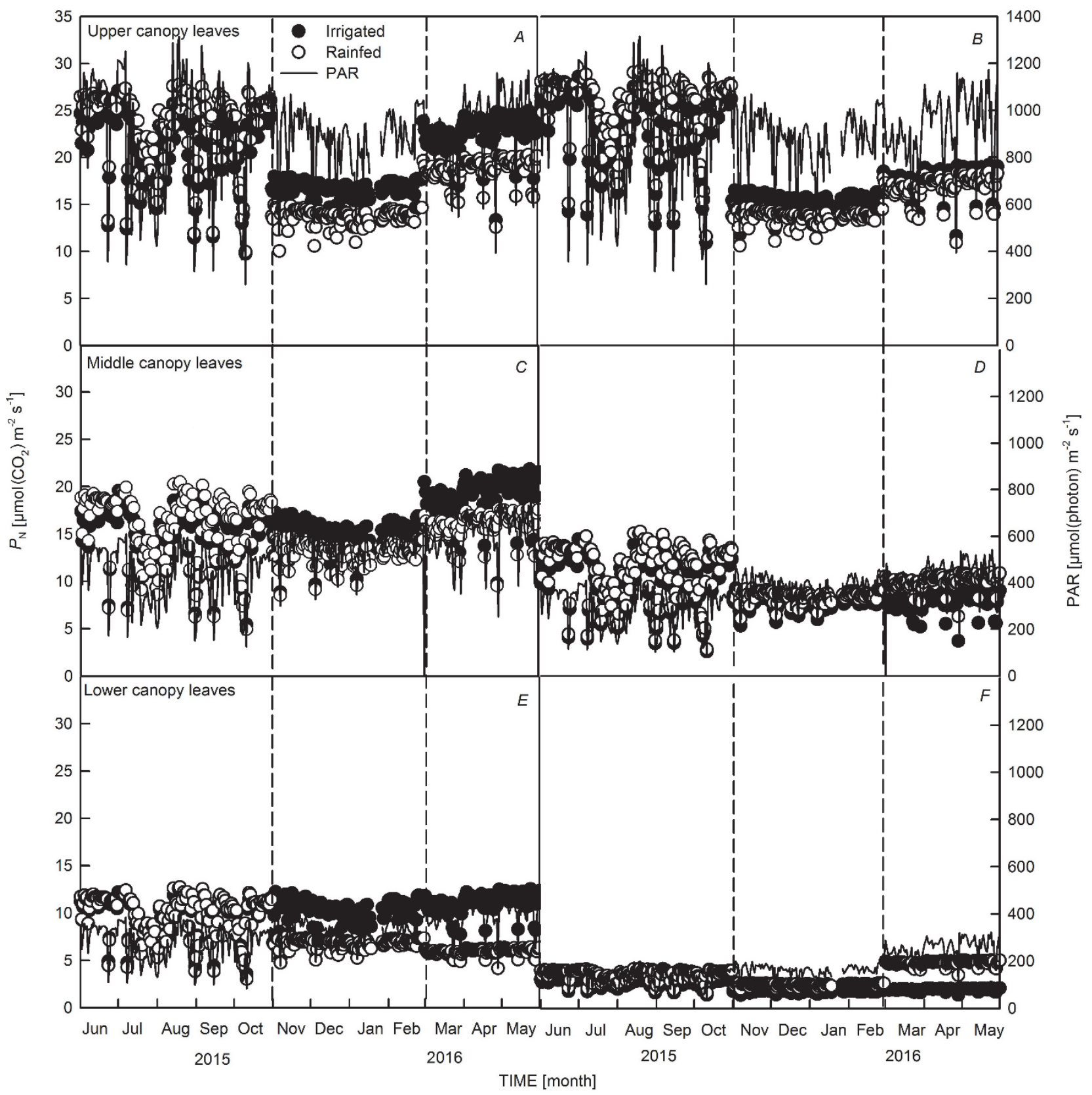

Fig. 4. Predicted year-round net photosynthetic rates for the upper, middle, and lower canopy leaves of cassava cv. RY 9 at the age of 3 $(A, C, E)$ and $6(B, D, F)$ months after planting under irrigated (dark circles) and rain-fed conditions (clear circles) in rainy $(A, B)$, cool $(C, D)$, and hot $(E, F)$ seasons.

moderate temperatures (Table 2). In general, the highest $P_{\text {Nmax }}$ were achieved during the rainy season followed by the hot and the lowest were found in the cool season (except the irrigated 3-month-old plants in which no seasonal differences were observed) (Figs. 2,3; Table 2). This trend of lowered $P_{\mathrm{N}}$ at low temperature in cassava genotypes was similarly demonstrated by El-Sharkawy et al. (2012) who reported average $P_{\mathrm{N}}$ range of 15.7-17.3 $\mu \mathrm{mol}\left(\mathrm{CO}_{2}\right) \mathrm{m}^{-2} \mathrm{~s}^{-1}$ in the cool sub-humid climate (mean annual temperature of $\left.\mathrm{ca} .1^{\circ} \mathrm{C}\right)$ and 24.6-27.6 $\mu \mathrm{mol}\left(\mathrm{CO}_{2}\right)$ $\mathrm{m}^{-2} \mathrm{~s}^{-1}$ in the warm sub-humid climate (mean annual temperature of $c a \cdot 24^{\circ} \mathrm{C}$ ). At $20^{\circ} \mathrm{C}$, net photosynthetic rate of a hot-climate cultivar (M Bra 12), which normally had an optimum temperature for photosynthesis at $30^{\circ} \mathrm{C}$, was reduced by $50 \%$ if the plants were grown under the cool climate and rain-fed field conditions (El-Sharkawy 2006). The major constraint attributing to low net photosynthetic rates in the cool season was the low RH (Table 1) which induced stomatal closure (Bauer et al. 2013) leading to considerably lower stomatal conductance $\left(g_{\mathrm{s}}\right)$ values (Figs. $1 A, B, 2 A, B$; Table 1) than those in the rainy and hot seasons. However, El-Sharkawy and Cock (1990) reported 
Table 4. Hyperbola; modified hyperbola III equation of photosynthetic light-response curves which were used to predict the year round photosynthetic rates of cassava cv. RY9 at the age of three and six months after planting (MAP) under irrigated and rain-fed conditions in rainy, cool, and hot seasons.

Season

3 MAP Irrigated

Rainfed

$\begin{array}{ll}\text { Upper canopy leaves } \\ \text { Rainy } & \mathrm{y}=30.1839-32.2036 /(1+0.0003 \mathrm{x})^{\wedge}(1 / 0.1658) \\ \text { Cool } & \mathrm{y}=31.0726-33.2985 /(1+0.0039 \mathrm{x})^{\wedge}(1 / 1.7729) \\ \text { Hot } & \mathrm{y}=33.1742-36.2115 /(1+0.0007 \mathrm{x})^{\wedge}(1 / 0.4038)\end{array}$

$\mathrm{y}=33.0343-36.3047 /(1+0.0004 \mathrm{x})^{\wedge}(1 / 0.2187)$
$\mathrm{y}=35.0926-38.5635 /(1+0.0058 \mathrm{x})^{\wedge}(1 / 3.0571)$
$\mathrm{y}=24.9409-27.7280 /(1+0.0014 \mathrm{x})^{\wedge}(1 / 0.5435)$

Middle canopy leaves

Rainy $\quad \mathrm{y}=28.9789-30.6982 /(1+0.0011 \mathrm{x})^{\wedge}(1 / 0.4633)$

Cool $\quad \mathrm{y}=34.1700-37.9082 /(1+0.0010 \mathrm{x})^{\wedge}(1 / 0.6256)$

Hot $\quad \mathrm{y}=33.9340-36.2698 /(1+0.0005 \mathrm{x})^{\wedge}(1 / 0.2741)$

$\mathrm{y}=33.0672-35.5889 /(1+0.0006 \mathrm{x})^{\wedge}(1 / 0.3228)$

$\mathrm{y}=641536.8727-641539.6911 /(1+0.0069 \mathrm{x})^{\wedge}(1 / 64414.3444)$

$\mathrm{y}=23.3425-25.8384 /(1+0.0011 \mathrm{x})^{\wedge}(1 / 0.4108)$

Lower canopy leaves

Rainy $\quad \mathrm{y}=18.3512-19.6490 /(1+0.0020 \mathrm{x})^{\wedge}(1 / 0.5282)$

Cool $\quad \mathrm{y}=35.4098-38.2899 /(1+0.0009 \mathrm{x})^{\wedge}(1 / 0.5689)$

Hot $\quad \mathrm{y}=19.9267-21.4356 /(1+0.0015 \mathrm{x})^{\wedge}(1 / 0.4756)$

$\mathrm{y}=22.0606-23.7973 /(1+0.0015 \mathrm{x})^{\wedge}(1 / 0.4966)$

$\mathrm{y}=14.0273-16.1969 /(1+0.0074 \mathrm{x})^{\wedge}(1 / 1.5988)$

$\mathrm{y}=9.3938-11.0041 /(1+0.0110 \mathrm{x})^{\wedge}(1 / 1.5124)$

6MAP

Upper canopy leaves

$\begin{array}{ll}\text { Rainy } & \mathrm{y}=30.7446-33.2498 /(1+0.0002 \mathrm{x})^{\wedge}(1 / 0.0983) \\ \text { Cool } & \mathrm{y}=27.3520-30.2973 /(1+0.00478 \mathrm{x})^{\wedge}(1 / 1.7712) \\ \text { Hot } & \mathrm{y}=24.8566-27.3028 /(1+0.0016 \mathrm{x})^{\wedge}(1 / 0.6722)\end{array}$

$\mathrm{y}=32.8706-35.4781 /(1+0.0003 \mathrm{x})^{\wedge}(1 / 0.1469)$

$\mathrm{y}=25.2453-27.6243 /(1+0.0054 \mathrm{x})^{\wedge}(1 / 1.9957)$

$\mathrm{y}=23.5397-26.7254 /(1+0.0014 \mathrm{x})^{\wedge}(1 / 0.5852)$

Middle canopy leaves

Rainy $\quad \mathrm{y}=24.1392-26.3223 /(1+0.0002 \mathrm{x})^{\wedge}(1 / 0.0794)$

Cool $\quad \mathrm{y}=32.9818-35.4243 /(1+0.0104 \mathrm{x})^{\wedge}(1 / 4.3982)$

Hot $\quad \mathrm{y}=19.5747-21.8058 /(1+0.0032 \mathrm{x})^{\wedge}(1 / 1.0153)$

$\mathrm{y}=29.1802-31.3613 /(1+0.0004 \mathrm{x})^{\wedge}(1 / 0.2022)$

$\mathrm{y}=29.1595-31.1542 /(1+0.0127 \mathrm{x})^{\wedge}(1 / 4.4132)$

$\mathrm{y}=14.6618-17.0432 /(1+0.0026 \mathrm{x})^{\wedge}(1 / 0.6797)$

Lower canopy leaves

Rainy $\quad \mathrm{y}=13.8444-15.1772 /(1+0.0012 \mathrm{x})^{\wedge}(1 / 0.2696) \quad \mathrm{y}=15.8239-18.1395 /(1+0.0007 \mathrm{x})^{\wedge}(1 / 0.1775)$

Cool $\quad \mathrm{y}=14368.7486-14370.7153 /\left(1+0.0336 \mathrm{y}=39.5985-41.4006 /(1+0.0371 \mathrm{x})^{\wedge}(1 / 14.1182)\right.$ $\mathrm{x})^{\wedge}(1 / 5897.5185)$

Hot $\quad \mathrm{y}=9.0710-10.3997 /(1+0.0114 \mathrm{x})^{\wedge}(1 / 1.6534)$

$\mathrm{y}=7.7020-9.9460 /(1+0.0044 \mathrm{x})^{\wedge}(1 / 0.7542)$

that when leaf-air vapor pressure difference (VPD) was kept at a low level during gas-exchange measurement, $g_{\mathrm{s}}$ increased with leaf temperature (measured leaf temperature ranged from $12-45^{\circ} \mathrm{C}$ ). Compared to several woody and herbaceous species, cassava was more sensitive to changes in air humidity, and $g_{\mathrm{s}}$ was negatively correlated with the VPD (El-Sharkawy 1990). Cassava possesses a tight stomatal control over leaf gas exchange that reduces transpiration rates (Figs. 1-3) when plants are subjected to soil water deficits as well as to high atmospheric evaporative demands, thus protecting leaves from severe dehydration (El-Sharkawy 2007).

In this study, photosynthesis performance of cassava was greater in the hot than the cool season despite an exposure to the most intense PAR (Fig. 1) and temperatures as high as $44^{\circ} \mathrm{C}$ for several days during March-May 2016 (Table 1). In April, plants can experience maximum temperature range of $42-44^{\circ} \mathrm{C}$ for $2-4 \mathrm{~h}$ before noon and during early afternoon. As suggested by El-Sharkawy (2006), cassava possesses a large photosynthetic capacity that can be fully expressed in hot humid climate with high solar radiation. For example, in the Patia Valley, Southwestern Colombia [altitude $560 \mathrm{~m}$, mean daily temperature $29^{\circ} \mathrm{C},>70 \% \mathrm{RH}$, solar irradiance $>1,800$ $\mu$ mol(photon) $\mathrm{m}^{-2} \mathrm{~s}^{-1}$, maximum photosynthetic rates around 30-36 $\mu \mathrm{mol}\left(\mathrm{CO}_{2}\right) \mathrm{m}^{-2} \mathrm{~s}^{-1}$ were common across several cultivars with leaf temperature in the range of 32$37^{\circ} \mathrm{C}$ and bright sunlight. Tolerance to high temperatures in cassava has been well documented (Fermont et al. 2009).

Interestingly, the seasonal variation in net photosynthetic rates was more prominent under rain-fed than irrigated conditions. For the irrigated 3-month-old plants, seasonal differences in $P_{\mathrm{Nmax}}$ at each leaf position were not significantly different whereas those of the rain-fed plants (taken $P_{\text {Nmax }}$ of upper canopy leaves as an example) showed significantly lower $P_{\text {Nmax }}$ in the cool $(40 \%$ reduction) and the hot (23\% reduction) season compared to that in the rainy season (Table 2). In the cool and hot seasons, significantly lower $P_{\mathrm{Nmax}}$ in the rain-fed plants compared to the irrigated ones was associated with low rainfalls $(0 \mathrm{~mm}$ in December $2015-81.0 \mathrm{~mm}$ in April 2016), progressively lower soil matric potentials in the rain-fed fields as well as lower RH (Table 1). As shown in Table 1S (supplement available online), the lowest range of $g_{\mathrm{s}}$ in response to light intensity was found under the 
rain-fed conditions in the cool season. Air humidity affects photosynthesis indirectly through control over intercellular $\mathrm{CO}_{2}$, as stomata tend to close in dry air resulting in lower $g_{\mathrm{s}}$ (Kaiser et al. 2015). Stomatal closure is driven by low light, high $\mathrm{CO}_{2}$, low temperature, and low $\mathrm{RH}$ (high VPD) (Outlaw 2003). In the natural environment, these factors exert compound effects on stomatal movement with RH as a key factor (Talbott et al. 2003) and stomatal responses to change in dry air are considered to be related also to leaf water status (Lawson et al. 2010, Kaiser et al. 2015). According to Flexas et al. (2002), who analyzed data from 59 published articles, concluded that plants having $g_{\mathrm{s}}>0.15 \mathrm{~mol}\left(\mathrm{H}_{2} \mathrm{O}\right) \mathrm{m}^{-2} \mathrm{~s}^{-1}$ are considered under non-stress or mild water stress; $0.15>g_{\mathrm{s}}>0.10 \mathrm{~mol}\left(\mathrm{H}_{2} \mathrm{O}\right)$ $\mathrm{m}^{-2} \mathrm{~s}^{-1}$ moderate water stress, and $0.1>g_{\mathrm{s}}>0.05$ $\operatorname{mol}\left(\mathrm{H}_{2} \mathrm{O}\right) \mathrm{m}^{-2} \mathrm{~s}^{-1}$ severe water stress. In this study, $g_{\mathrm{s}}$ values of rain-fed plants in rainy season [0.31-1.01 $\left.\operatorname{mol}\left(\mathrm{H}_{2} \mathrm{O}\right) \mathrm{m}^{-2} \mathrm{~s}^{-1}\right]$ were much higher than $0.15 \mathrm{~mol}\left(\mathrm{H}_{2} \mathrm{O}\right)$ $\mathrm{m}^{-2} \mathrm{~s}^{-1}$ indicating that cassava plants in the rainy season were exposed to favorable conditions with respect to soil and air moisture. The lowest observed $g_{\mathrm{s}}$ (at maximum light intensity) in rain-fed plants (upper canopy leaves) was 0.1 and $0.29 \mathrm{~mol}\left(\mathrm{H}_{2} \mathrm{O}\right) \mathrm{m}^{-2} \mathrm{~s}^{-1}$ during the cool and hot seasons which corresponded to 28 and $22 \%$ reduction (compared to corresponding leaves at the irrigated fields) in net photosynthetic rates, respectively (Table $1 \mathrm{~S}$ ). Although lower $g_{\mathrm{s}}$ in the cool and hot seasons led to lower net photosynthetic rates than those in the rainy season, it apparently functioned in conserving water as indicated by higher WUE values (Table 1S). Therefore, cassava leaves under rain-fed conditions, in this study, was considered to be under mild water stress during the cool and hot seasons despite low soil water potentials and five months of extremely low rainfalls (Table 1). In addition to rapidly decreasing $g_{\mathrm{s}}$, cassava is capable of forming deep root system that allows the crop to have access to deep water layers as an escape mechanism to avoid water stress (ElSharkawy 2004, Okogbenin et al. 2013). Moreover, cassava leaves normally droop, to decrease interception of sunlight, thereby decreasing leaf temperature and water loss (El-Sharkawy 2004, 2007). A decline in $g_{\mathrm{s}}$ under mild water stress, although imposes stomatal limitations causing a decrease in net photosynthetic rates, may have protective effects against stress, by allowing plant water saving and improving plant WUE (Chaves et al. 2009). In addition to stomatal limitations under mild water stress, Flexas and Medrano (2002) also suggested that contents of ribulose-1,5-bisphosphate (RuBP) and ATP could be decreased in early drought development, indicating that the process of RuBP regeneration and ATP synthesis are impaired at still relatively high $g_{\mathrm{s}}$ [higher than $0.15 \mathrm{~mol}\left(\mathrm{H}_{2} \mathrm{O}\right) \mathrm{m}^{-2} \mathrm{~s}^{-1}$ leading to lower net $\mathrm{CO}_{2}$ assimilation rate. When field-grown cassava was deprived of water for 8 weeks starting at $3 \mathrm{MAP}$, the $\mathrm{C}_{3}$ Rubisco activity in leaf extracts was reduced by about $40 \%$, while the $\mathrm{C}_{4}$ PEPC increased by $13 \%$, suggesting the adaptive advantage under stress of the $\mathrm{C}_{4}$ enzyme system (ElSharkawy 2004).

Seasonal response in photosynthesis capacity also varied with the plant age. In general, $P_{\mathrm{Nmax}}$ of leaves at the same positions in each season of the 3-months-old were consistently higher than those of the 6-month-old plants (Table 2). Under irrigated conditions, $P_{\mathrm{Nmax}}$ for the leaves of the 3-month-old plants did not differ significantly between the three seasons; significant differences were noted only for rain-fed plants. In contrast, leaves of the 6-month-old plants, under both water regimes, exhibited significantly higher $P_{\mathrm{Nmax}}$ in the rainy than the cool and hot seasons. Therefore, sensitivity of leaves to environmental conditions varies with the plant age. The trend in declining photosynthetic rates with the plant age was previously demonstrated by El-Sharkawy (2007) in eight cassava varieties. Average $P_{\mathrm{N}}$ in the 2-month-old plants of those varieties was approximately $30 \mu \mathrm{mol}\left(\mathrm{CO}_{2}\right) \mathrm{m}^{-2} \mathrm{~s}^{-1}$ while at six months of their age it was reduced by $50 \%$ to approximately $15 \mu \mathrm{mol}\left(\mathrm{CO}_{2}\right) \mathrm{m}^{-2} \mathrm{~s}^{-1}$. Studies from a variety of experimental situations generally indicated that photosynthesis is reduced with the age of shrubs and trees (Bond 2000). This age-related variation in photosynthetic rate was reported to occur due to the effects of development on the timing of tissue senescence and the longevity of leaves (Hensel et al. 1993). Cassava was reported to be sensitive to drought stress during its establishment period (from planting to about three months after planting) (Mulualem and Bekeko 2015). ElSharkawy (2007) showed that $P_{\mathrm{N}}$ was reduced under water stress imposed to plants at the age of two to six months. The percent reduction in $P_{\mathrm{N}}$ due to water stress was high in younger plants and became almost insignificant in the 6-month-old plants. This observation was similar to our results in the cool and hot seasons, i.e., differences in photosynthetic capacity between rain-fed and irrigated plants were more pronounced in the 3-month-old than that in the 6-month-old plants (Table 2). Photosynthetic capacity of cassava also varied with leaf age and position. Typically, the $P_{\text {Nmax }}$ of the upper canopy was higher than the middle and lower canopy leaves (Table 2). Due to the influence of light exposure at each leaf position, the upper canopy leaves receive full sunlight resulting in the highest $P_{\mathrm{N}}$, followed by middle and lower canopy leaves. Plant canopies are characterized by major reductions in light availability from canopy top to bottom )Hikosaka 2005, 2014; Kitajima et al. 2005). The strong within-canopy light gradients are further associated with conspicuous within-canopy variations in foliage structural, chemical, and physiological traits. As suggested by Niinemets et al. (2015), for plants with continuous expanding canopies, the within-canopy gradient in $P_{\mathrm{N}}$ reflects gradients in leaf age and re-acclimation to shade or leaf senescence in shade. Older leaves are expected to be overtopped by younger leaves, and thus, it is predicted that the light availability incident to older leaves decreases with increasing leaf age 
(Niinemets 2016). In this study, photosynthesis performance of the lower canopy leaves of the 6-month-old plants, having closed dense canopy (higher LAI), was much lower, and the light-response pattern was more shade-acclimated than those of the more-open-canopy 3-month-old plants (Figs. 2, 3). This reflects that the within-canopy variation was affected by light availability, leaf age and plant age. Other studies in cassava also revealed that the young leaves exhibited a higher $P_{\text {Nmax }}$ than mature leaves in both control and water stressed plants (Calatayud et al. 2000, de Tafur et al. 1997). Cassava leaves at the age of two weeks had the highest photosynthetic rate (corresponding to the upper canopy leaves), which decreased as the leaves mature (Aslam et al. 1977). The leaf age of rice was dominant in determining $P_{\text {Nmax }}$ in upper leaves, whereas acclimation to irradiance levels was of greater importance for the lower leaves (Murchie et al. 2002). Other related light-response parameters including $R_{\mathrm{D}}$ and $I_{\text {comp }}$ also varied with plant age, leaf age and position in the same way as $P_{\mathrm{N}}$, i.e., $R_{\mathrm{D}}$ and $I_{\text {comp }}$ tended to be lower in older plants, and declining with lower shaded leaf positions. Lower $R_{\mathrm{D}}$ and $I_{\text {comp }}$ in shade or older leaves allows for the maintenance of positive carbon balance under low light intensity (Catoni et al. 2015).

The maximum $P_{\mathrm{Nmax}}$ recorded for cassava in this study was $31 \mu \mathrm{mol}\left(\mathrm{CO}_{2}\right) \mathrm{m}^{-2} \mathrm{~s}^{-1}$ (Table 2) which occurred in the top canopy leaves under the most favorable environments in the rainy season. This $P_{\mathrm{Nmax}}$ value was much below the maximal rates of $40 \mu \mathrm{mol}\left(\mathrm{CO}_{2}\right) \mathrm{m}^{-2} \mathrm{~s}^{-1}$ previously reported by El-Sharkawy et al. (1992a). The difference might be due to genotypic variation in structural and biochemical characteristics, different growing environments, as well as feedback inhibition of photosynthesis resulting from difference in sink size and capacity (Cock et al. 1979, Rosenthal et al. 2012).

Comparison between the light-response curve parameters (Figs. 2, 3; Table 2) and the year round net photosynthetic rates (Fig. 4; Table $2 \mathrm{~S}$ ) predicted using the daily average measured light intensity revealed that photosynthesis performance of cassava leaves under natural light conditions is below their maximum photosynthesis capacity. The pattern of predicted net photosynthetic rates differed between seasons, with the most fluctuations occurred in the rainy season due to a great number of rainy and overcast days. For both 3- and 6-month-old plants in the rainy season, the average predicted photosynthetic rates of the upper and middle canopy leaves under the rainfed conditions tended to be slightly higher than those under the irrigated conditions (Fig. 4, Table 2S). This indicates that cassava plants in the rain-fed fields received favorable amount of rain water and there would be no need for irrigation for cassava growing in rainy season in this type of climate as long as the plants were well watered during the first month after planting. Rainy season also provided optimum temperatures and $\mathrm{RH}$ for both water regimes (Table 1). Available sunlight seemed to be the most important limiting factor for cassava plants growing in rainy season. El-Sharkawy and de Tafur (2010) also observed the maximum $P_{\mathrm{N}}$ of close to $30 \mu \mathrm{mol}\left(\mathrm{CO}_{2}\right)$ $\mathrm{m}^{-2} \mathrm{~s}^{-1}$ in the upper canopy leaves of the 2- to 3-month-old cassava cv. M Bra 900 in the wet season. The $P_{\mathrm{N}}$ of this cultivar, however, reduced to approximately $10 \mu \mathrm{mol}\left(\mathrm{CO}_{2}\right) \mathrm{m}^{-2} \mathrm{~s}^{-1}$ at the age of 5 months after a period of drought. Finally, at the age of six months, $P_{\mathrm{N}}$ recovered back to approximately $20 \mu \mathrm{mol}\left(\mathrm{CO}_{2}\right) \mathrm{m}^{-2} \mathrm{~s}^{-1}$ after receiving some rain.

The variation among seasons was the most prominent in the upper canopy leaves which received full solar radiation. However, the difference in the predicted net photosynthetic rates between rainy/hot seasons and the cool season diminished in the middle canopy leaves and was almost indistinguishable for the lower canopy leaves (Fig. 4, Table 2S). This is due to the difference in canopy size of the plants in different seasons. The percentage light penetration to the lower canopy leaves of the 3-month-old irrigated plants was lower in the rainy $(24 \%)$ than in the cool $(34 \%)$ and the hot (38\%) seasons (Fig. 7S), therefore making small difference in the amount of light interception by the lower canopy leaves in all three seasons.

The predicted net photosynthetic rates of the 6-monthold plants were mostly lower than those of the 3-monthold plants (except the upper canopy leaves in the rainy season). The maximum predicted performance of the upper canopy leaves of the irrigated 6-month-old plants in the rainy season (Table $2 \mathrm{~S}$ ) was similar to the $P_{\mathrm{Nmax}}$ from the $P_{\mathrm{N}} / I$ curve (Table 2 ). However, similar to the 3 -monthold plants, maximum predicted performance in the cool and hot seasons (Table $2 \mathrm{~S}$ ) was lower than the maximum potential photosynthesis capacity $\left(P_{\mathrm{Nmax}}\right)$ determined from the $P_{\mathrm{N}} / I$ curves (Table 2 ). Compared to the 3-month-old plants, the predicted performance of the middle and lower canopy leaves of the 6-month-old plants was extremely low (Table 2S), due to the dense canopy, in the rainy and hot seasons, which allowed only $13-14 \%$ light penetration to the lower canopy leaves (Fig. 7S). The lower canopy leaves of the irrigated 6-month-old plants maintained very low positive carbon balance $\left[2.1,3.1\right.$, and $4.7 \mu \mathrm{mol}\left(\mathrm{CO}_{2}\right)$ $\mathrm{m}^{-2} \mathrm{~s}^{-1}$ in the cool, hot and rainy season, respectively]. Considering that the lower canopy leaves used to construct the light-response curves were at the middle of the lower third of the canopy, there would be approximately ten leaves further down the canopy, which are expected to have lower $P_{\mathrm{N}}$ or close to zero net photosynthesis (data not shown). Therefore, it is expected that the lower canopy leaves of the 6-month-old plants contributed by a very small amount of photosynthates to the growing storage roots. Previous literature stated that cassava plants achieve maximum vegetative growth and canopy development (leaf and stem growth) at the age of three months (Alves 2002), therefore leaves of the 3-month-old plants were photosynthetically more active than those of older plants (Calatayud et al. 2000). After the canopy of cassava started to develop at about $15 \mathrm{~d}$ after planting until the plants 
achieved maximum leaf area index at six months after planting, photoassimilates were mostly invested to shoot (stem and leaf) development (Alves 2002). From six months after planting, photoassimilates are then preferentially partitioned to the storage tuberous roots. In addition to environmental factors, individual leaf photosynthetic activity of the 6-month-old and older plants could also be controlled by sink capacity which may exert feedback control over photosynthetic performance (de Souza et al. 2017).

In Thailand, there are two normal planting seasons, i.e., pre-rainy during late April to June and post-rainy season crop during early October to late November. For the prerainy season crop, the maximum vegetative development and net photosynthetic rates are achieved during the rainy season, and no irrigation is needed. However, for the postrainy season crop, in which maximum vegetative growth occurs during the cool and hot season, irrigation is beneficial for enhancing net photosynthetic rates.

In conclusion, the photosynthetic light-response curves

\section{Reference}

Adjebeng-Danquah J., Gracen V.E., Offei S.K. et al.: Genetic variability in storage root bulking of cassava genotypes under irrigation and no irrigation. - Agric. Food Secur. 5: 9, 2016.

Alves A.A.C.: Cassava botany and physiology. - In: Hillocks R.J., Thresh J.M., Bellotti A.C. (ed.): Cassava: Biology, Production and Utilization. Pp. 67-90. CABI Publishing, New York 2002.

Aslam M., Lowe S.B., Hunt L.A.: Effect of leaf age on photosynthesis and transpiration of cassava (Manihot esculenta). Can. J. Bot. 55: 2288-2295, 1977.

Bauer H., Ache P., Lautner S. et al.: The stomatal response to reduced relative humidity requires guard cell-Autonomous ABA synthesis. - Curr. Biol. 23: 53-57, 2013.

Bond B.J.: Age-related changes in photosynthesis of woody plants. - Trends Plant Sci. 5: 349-353, 2000.

Calatayud P.A., Llovera E., Bois J.F. et al.: Photosynthesis in drought adapted cassava. - Photosynthetica 38: 97-104, 2000.

Catoni R., Granata M.U., Sartori F. et al.: Corylus avellana responsiveness to light variations: morphological, anatomical, and physiological leaf traits plasticity. - Photosynthetica 53: 35-46, 2015.

Chaves M.M., Flexas J., Pinheiro C.: Photosynthesis under drought and salt stress: regulation mechanisms from whole plant to cells. - Ann. Bot.-London 103: 551-560, 2009.

Cock J.H., Franklin D., Sandoval G. et al.: The ideal cassava plant for maximum yield. - Crop Sci. 19: 271-279, 1979.

de Souza A.P., Massenburg L.N., Jaiswal D. et al.: Rooting for cassava: insights into photosynthesis and associated physiology as a route to improve yield potential. - New Phytol. 213: 50-65, 2017.

de Tafur S.M., El-Sharkawy M.A., Calle F.: Photosynthesis and yield performance of cassava in seasonally dry and semi-arid environments. - Photosynthetica 33: 249-257, 1997.

Edet M.A., Tijani-Eniola H., Lagoke S.T.O. et al.: Relationship of cassava growth parameters with yield, yield related components and harvest time in Ibadan, Southwestern Nigeria. constructed from cassava leaves growing in three different seasons were used to predict daily net photosynthetic rates the leaves could perform throughout the year based on the recorded daily average radiation. In each season, under available daily average solar radiation, cassava leaves photosynthesized at the rates below their maximum potential rates determined from their light-response curves, particularly the middle and lower canopy leaves. Therefore, increased total canopy photosynthesis could be achieved through breeding for optimum canopy parameters to increase light interception efficiency and finally root yield (Lahai 2013, de Souza et al. 2017). In addition, de Souza et al. (2017) also suggested a major breeding opportunity for increasing efficiency of conversion of intercepted PAR to biomass through increasing net photosynthetic rates. Since photosynthetic rates differed widely between seasons, plant age, and canopy position, in any attempts to determine relationships among biomass, root yield, and single leaf photosynthetic rates, these variations should be taken into consideration.

- J. Nat. Sci. Res. 5: 87-92, 2015.

El-Sharkawy M.A., Cock J.H.: Water use efficiency of cassava. I. Effects of air humidity and water stress on stomatal conductance and gas exchange. - Crop Sci. 24: 497-502, 1984. El-Sharkawy M.A., Cock J.H.: Photosynthesis of cassava (Manihot esculenta). - Exp. Agr. 26: 325-340, 1990.

El-Sharkawy M.A., de Tafur S.M., Cadavid L.F.: Photosynthesis of cassava and its relation to crop productivity. Photosynthetica 28: 431-438, 1993.

El-Sharkawy M.A., de Tafur S.M., Cadavid L.F.: Potential photosynthesis of cassava as affected by growth conditions. Crop Sci. 32: 1336-1342, 1992a.

El-Sharkawy M.A., de Tafur S.M., Lopez Y.: Eco-physiological research for breeding improved cassava cultivars in favorable and stressful environments in tropica/subtropical bio-systems. - Environ. Res. 6: 143-211, 2012.

El-Sharkawy M.A., de Tafur S.M.: Comparative photosynthesis, growth, productivity, and nutrient use efficiency among tall and short stemmed rainfed cassava cultivars. - Photosynthetica 48: 173-188, 2010.

El-Sharkawy M.A., de Tafur S.M.: Genotypic and within canopy variation in leaf carbon isotope discrimination and its relation to short term leaf gas exchange characteristics in cassava grown under rainfed conditions in the tropics. - Photosynthetica 45: 515- 526, 2007.

El-Sharkawy M.A., Hernandez A.D., Hershey C.: Yield stability of cassava during prolonged mid-season water-stress. - Exp. Agr. 28: 165-174, 1992b.

El-Sharkawy M.A.: Cassava biology and physiology. - Plant Mol. Biol. 53: 621-641, 2003.

El-Sharkawy M.A.: Cassava biology and physiology. - Plant Mol. Biol. 56: 481-501, 2004.

El-Sharkawy M.A.: Cassava: physiological mechanisms and plant traits underlying tolerance to pro-longed drought and their application for breeding cultivars in the seasonally dry and semiarid tropics. - In: da Matta F.M. (ed.): Ecophysiology of 
Tropical Tree Crops. Pp 71-110. Nova Science Publishers, Hauppauge, New York 2010.

El-Sharkawy M.A.: International research on cassava photosynthesis, productivity, ecophysiology, and responses to environmental stresses in the tropics. - Photosynthetica 44: 481512,2006

El-Sharkawy M.A.: Physiological characteristics of cassava tolerance to prolonged drought in the tropics: Implications for breeding cultivars adapted to seasonally dry and semiarid environments. - Braz. J. Plant Physiol. 19: 257-286, 2007.

El-Sharkawy M.A.: Pioneering research on $\mathrm{C}_{4}$ photosynthesis: Implications for crop water relations and productivity in comparison to $\mathrm{C}_{3}$ cropping systems. - J. Food Agric. Environ. 7: 132-148, 2009a.

El-Sharkawy M.A.: Pioneering research on $\mathrm{C}_{4}$ leaf anatomical, physiological and agronomic characteristics of tropical monocot and dicot plant species: Implications for crop water relations and productivity in comparison to $\mathrm{C}_{3}$ cropping systems. - Photosynthetica 47: 163-183, 2009b

El-Sharkawy M.A.: Prospects of photosynthetic research for increasing agricultural productivity, with emphasis on the tropical $\mathrm{C}_{4}$ Amaranthus and the cassava $\mathrm{C}_{3}-\mathrm{C}_{4}$ crops. Photosynthetica 54: 161-184, 2016.

El-Sharkawy M.A.: Stress tolerant cassava: The role of integrative eco-physiology breeding research in crop improvement. - Open J. Soil Sci. 2: 162-186, 2012.

El-Sharkawy M.A.: Effects of humidity and wind on leaf conductance of field grown cassava. - Rev. Bras. Fisiol. Veget. 2: 17-22, 1990.

FAO: Cassava, production quantity (tons) for all countries. http://www.factfish.com/statistic/cassava $\% 2 \mathrm{C} \% 20$ production $\% 20$ quantity, 2016.

Fermont A.M., Asten P.J.A., Tittonell P. et al.: Closing the cassava yield gap: an analysis from small holder farms in East Africa. - Field Crop. Res. 112: 24-36, 2009.

Flexas J., Medrano H.: Drought inhibition of photosynthesis in $\mathrm{C}_{3}$ plants: stomatal and non-stomatal limitations revisited. Ann. Bot.-London 89: 183-189, 2002.

Flexas J., Bota J., Escalona J.M. et al.: Effects of drought on photosynthesis in grapevines under field conditions: an evaluation of stomatal and mesophyll limitations. - Funct. Plant Biol. 29: 461-471, 2002.

Freed R.D., Nissen O.: MSTAT-C version 1.42. Michigan State University, East Lansing, Michigan 1992.

Gao K., Chen F., Yuan L. et al.: A comprehensive analysis of root morphological changes and nitrogen allocation in maize in response to low-nitrogen stress. - Plant Cell Environ. 38: 740750, 2015.

Gomez K.A., Gomez A.A.: Statistical Procedures for Agricultural Research. Pp. 1-628. John Wiley \& Sons, New York 1984.

Habermann G., Machado E.C., Rodrigues J.D. et al.: $\mathrm{CO}_{2}$ assimilation, photosynthetic light response curves, and water relations of Pera sweet orange plants infected with Xylella fastidiosa. - Braz. J. Plant Physiol. 15: 79-87, 2003.

Hensel L.L., Grbić V., Baumgarten D.A. et al.: Developmental and age related processes that influence the longevity and senescence of photosynthetic tissues in Arabidopsis. - Plant Cell 5: 553-564, 1993.

Heschel M.S., Sultan S.E., Glover S. et al.: Population differentiation and plastic responses to drought stress in the generalist annual Polygonum persicaria. - Int. J. Plant Sci. 165: 817-824, 2004.
Hikosaka K.: Leaf canopy as a dynamic system: ecophysiology and optimality in leaf turnover. - Ann. Bot.-London 95: 521533, 2005.

Hikosaka K.: Optimal nitrogen distribution within a leaf canopy under direct and diffuse light. - Plant Cell Environ. 37: 20772085,2014

Howeler R.H.: Cassava mineral nutrition and fertilization. - In: Hillocks R.J., Thresh J.M., Bellotti A.C. (ed.): Cassava: Biology, Production and Utilization. Pp. 115-147. CABI Publishing, New York 2002.

Kaiser E., Morales A., Harbinson J. et al.: Dynamic photosynthesis in different environmental conditions. - J. Exp. Bot. 66: 2415-2426, 2015.

Keating B.A., Evenson J. P.: Effect of soil temperature on sprouting and sprout elongation of stem cuttings of cassava (Manihot esculenta Crantz). - Field Crop. Res. 2: 241-251, 1979.

Keeratikasikorn P.: Soil of Northeast Thailand. Pp. 81-95. Faculty of Agriculture, Khon Kaen University, Khon Kaen 1991.

Khalifa A.J.N.: On the effect of cover tilt angle of the simple solar still on its productivity in different season and latitudes. Energ. Convers. Manage. 52: 431-436, 2011.

Kitajima K., Mulkey S.S., Wright J.: Variation in crown light utilization characteristics among tropical canopy trees. - Ann. Bot.-London 95: 535-547, 2005.

Lachapelle P.P., Shipley B.: Interspecific prediction of photosynthetic light response curves using specific leaf mass and leaf nitrogen content: effects of differences in soil fertility and growth irradiance. - Ann. Bot.-London 109: 1149-1157, 2012.

Lahai T.: Influence of canopy structure on yield of cassava cultivars at various consequences of an inland valley agroecosystem. - J. Agric. Biotech. Sustain. Dev. 5: 36-47, 2013.

Lawlor D.W.: Photosynthesis: Molecular, Physiological and Environment Processes, $3^{\text {rd }}$ ed. Pp. 9-318. Bios Sci. Publ., Oxford, 2001.

Lawson T., von Caemmerer S., Baroli I.: Photosynthesis and stomatal behavior. - Prog. Bot. 72: 265-304, 2010.

Lenis J.I., Calle F., Jaramillo G. et al.: Leaf retention and cassava productivity. - Field Crop. Res. 95: 126-134, 2006.

Lin M., Wang Z., He L. et al.: Plant photosynthesis irradiance curve responses to pollution shown non-competitive inhibited Michaelis-Kinetics. - PLoS ONE 10: e0142712, 2015.

Lobo F.D.A., de Barros M.P., Dalmagro H.J. et al.: Fitting net photosynthetic light-response curves with Microsoft Excel -a critical look at the models. - Photosynthetica 51: 445-456, 2013.

Mulualem T., Bekeko Z.: Assessment of conventional breeding on cassava and its physiological adaptive mechanisms: implication for moisture stress. - Asian J. Agric. Res. 9: 38-54, 2015.

Murchie E.H., Hubbart S., Chen Y. et al.: Acclimation of rice photosynthesis to irradiance under field conditions. - Plant Physiol. 130: 1999-2010, 2002.

Nassar N., Ortiz R.: Breeding cassava to feed the poor. - Sci. Am. 302: 78-84, 2010.

Newby J.: Cassava in Asia: Exposing the drivers and trajectories of the hidden ingredient in global supply chains. World Congress on Roots and Tubers Crops 18-22 January 2016, Nanning, China 2016.

Niinemets Ü.: Leaf age dependent changes in within-canopy variation in leaf functional traits: a meta-analysis. - J. Plant 
Res. 129: 313-338, 2016

Niinemets Ü., Keenan T.F., Hallik L.: Tansley review. A worldwide analysis of within-canopy variations in leaf structural, chemical and physiological traits across plant functional types. - New Phytol. 205: 973-993, 2015.

Okogbenin E., Setter T.L., Ferguson M. et al.: Phenotypic approaches to drought in cassava: review. - Front. Physiol. 4: $1-15,2013$.

Outlaw W.H., Jr.: Integration of cellular and physiological functions of guard cells. - Crit. Rev. Plant Sci. 22: 503-529, 2003.

Pellet D., El-Sharkawy M. A.: Cassava varietal response to phosphorus fertilization. I. Yield, biomass and gas exchange. Field Crop. Res. 35: 1-11, 1993.

Pignon C.P., Jaiswal D., McGrath J.M. et al.: Loss of photosynthetic efficiency in the shade. An Achilles heel for the dense modern stands of our most productive $\mathrm{C}_{4}$ crops? - J. Exp. Bot. 68: 335-345, 2017.

Prammanee S., Kamprerasart K., Salakan S. et al.: Growth and starch content evaluation on newly released cassava cultivars, Rayong 9, Rayong 7 and Rayong 80 at different harvest times. - Kasetsart J.-Nat. Sci. 44: 558-563, 2010.

Pujol B., Salager J.L., Beltran M. et al.: Photosynthesis and leaf structure in domesticated cassava (Euphorbiaceae) and a close wild relative: have leaf photosynthetic parameters evolved under domestication. - Biotropica 40: 305-312, 2008.

Ribeiro R.V., Machado E.C., Santos M.G. et al.: Photosynthesis and water relations of well-watered orange plants as affected by winter and summer conditions. - Photosynthetica 47: 215222, 2009.

Rosenthal D.M., Slattery R.A., Miller R.E. et al.: Cassava aboutFACE: greater than expected yield stimulation of cassava (Manihot esculenta) by future $\mathrm{CO}_{2}$ levels. - Glob. Change Biol. 18: 2661-2675, 2012.

Takeuchi Y., Kubiske M.E., Isebrands J.G. et al.: Photosynthesis, light and nitrogen relationships in a young deciduous forest canopy under open air $\mathrm{CO}_{2}$ enrichment. - Plant Cell Environ. 24: 1257-1268, 2001.

Talbott L.D., Rahveh E., Zeiger E.: Relative humidity is a key factor in the acclimation of the stomatal response to $\mathrm{CO}_{2}$. $-\mathrm{J}$. Exp. Bot. 54: 2141-2147, 2003.

Thai Meteorological Department: Season of Thailand. Dryad Digital Repository. https://www.tmd.go.th/info/info.php? FileID $=53,2016$.

Vongkasem W, Klakhaeng K., Hemvijit S. et al.: Reducing soil erosion in cassava production systems in Thailand: A farmer participatory approach. Proc. $6^{\text {th }}$ Regional Workshop on Cassava's Potential in Asia in the $21^{\text {st }}$ Century: Present Situation and Future Research and Development Needs, 21-25 Feb 2000. Pp. 402-412. Ho Chi Minh City, Vietnam 2000.

Zhang S., Ma K., Chen L.: Response of photosynthetic plasticity of Paeonia suffruticosa to changed light environments. Environ. Exp. Bot. 49: 121-133, 2003. 